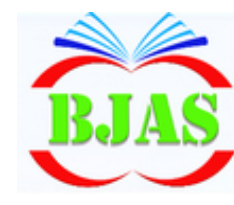

ISSN $1814-5868$
Available online at $\mathrm{http} / / / \mathrm{bjas} . b a j a s . e d u . i q$

https://doi.org/10.37077/25200860.2020.33.1.18

College of Agriculture, University of Bas rah

Basrah J. Agric. Sci. 33(1):231 - 260, 2020
Basrah Journal

of Agricultural

Sciences

E-ISSN: 2520-0860

\title{
Drying Klunzinger's Mullet Fish Planiliza klunzingeri Using Halogen Dryer and Modeling the Moisture Content with Artificial Neural Network
}

\author{
Hassan H. Al-Rubaiy*, Sabah M. Al- Shatty \& Asaad R. Al-Hilphy \\ Department of Food Science, College of Agriculture, University of Basrah, Iraq \\ *Corresponding author: Drhassanha78@gmail.com
}

Received 4 April 2020; Accepted 23 June 2020; Available online 30 June 2020

\begin{abstract}
Salted and unsalted Klunzinger's mullet Planiliza klunzingeri were dried using infrared halogen dryer with different temperatures $(60,65,70,75 \text { and } 80)^{\circ} \mathrm{C}$ and different storage periods $(0,7,14,21,28$ and 35$)$ days and studying their qualitative characteristics. The results showed that the moisture content decreased as drying time increased. The drying efficiency of the halogen dryer was $70.36 \%$ at $60{ }^{\circ} \mathrm{C}$ and decreased as the drying temperature increased. Chemical composition of dried fish (salted and unsalted) showed that the moisture percentage was decreased, but the percentage of protein, fat and ash was increased after drying process. The percentage of moisture increased during the storage periods $(0,7,14,21,28$ and 35) days, unlike the other chemical composition percentages were decreased with increasing storage periods. The results showed that the rehydration was decreased with the increase of drying temperatures for salted and unsalted dried fish. Moreover, the results showed that there was an increase in TBA after the drying process and during the storage periods. In addition, the results revealed that the microbial content of dried salted and unsalted fish was decreased. The results illustrated that the first order model can be used to predict $\mathrm{pH}$ value during storage periods. Artificial neural network (ANN) model had a good result of predicted moisture content.
\end{abstract}

Keywords: Fish, Planiliza klunzingeri artificial neural network, halogen dryer, qualitative characteristics, Microbiological content.

\section{Introduction}

Drying leads to stop food damage by stopping the activity of bacteria, fermentation, and enzymes (Gates, 2015). Dried foodstuffs retains its flavor and nutritional value, easy prepared as well as it is light weight (Scanlin, 1997). Drying processes have been known since ancient times as a food preservation method (Guiné, 2018; Dubey et al., 2020). The natural sun drying is one of the oldest conservation methods, which are known by humans and used by the people of the Arab countries to dry the fruits and vegetables from one season to another (Al-Rubai'y et al., 2020). The natural sun drying needs great areas, high temperatures, low moisture, no rainy weather and needs to long drying time (Lasisi et al., 2020). The natural sun drying method leads to occurrence of some negative changes in foodstuffs, and this related to the many factors, such as, weather conditions, pollution with microorganisms, dust and insects, this led to the non-exploitation economically on a large scale (Darvishi, et al., 2013). Pochont et al. (2020) and Solanki 
(2020) stated that the solar dryer has a better quality compared to open sun drying (natural sun drying). Dried fish should be stored in a hygienic cool and dry environment (Kubra et al., 2020).

Fish represents a high source of protein and fats (Nath et al., 2020). Fresh fish can be easily damaged, as well as its shelf life is short. The damage starts after 12 hours of fishing, especially in hot and warm weather (Darvishi, et al., 2013). Fish meat is spoiled by self-decomposition (enzymatic), chemical reactions (oxidative stress), microbial activity and by the combined of these three factors (Huss, 1995; Chen et al., 2020). In recent times, modern techniques have been used to drying fish. Kumar (2015) referred to the use of microwave drying technology or conventional oven in the drying processes. Fish dried with microwave gave a high drying efficiency. In addition, the increase in storage period of salted dried fish was higher than unsalted dried fish, and the possibility of using industrial solar collectors in drying different types of fish (Al-Rubaiy et al., 2020). Al-Temimi (2018) dried silver carp fish using microwave technology. Al-Fadhli (2009) dried Thelah fish (Scomberoides commersonnianus) using a solar dryer. Lithi et al. (2020) studied quality change of Mola (Amblypharyngodon mola) in open sun drying and solar tent dryer, the researchers found that the moisture content of Mola from solar tent dryer was significantly $(\mathrm{P}<0.05)$ lower compared to the open sun rack dryer and protein, lipid, ash and TVB-N content was significantly $(\mathrm{P}<0.05)$ higher in solar tent dried compared to the open sun rack dryer. Hardoko \& Utami (2020) declared that the boiling time and drying duration had an effect on the chemical-physical properties of the rambak crackers of white snapper fish skin. Infrared ray is used to dry food with high efficiency (Aboud et al., 2019). Al-Temimi et al. (2019) stated that the radio-frequency heating can be used for food drying. Halogen oven is characterized with highly effective when it is used as a source of energy, which converts more than $85 \%$ of its electric energy into thermal energy (Pan \& Atungulu, 2011). The same studies indicated that the use of halogen ovens to cook food is faster and cleaner than microwave ovens because of their characteristics are : the thermal emission outside the device is low and without fumes and there are not smells when they are used, in addition to that, the operating temperature ranges between $20-250^{\circ} \mathrm{C}$ (Pan \& Atungulu, 2011). Al-Hilphy, et.al. (2011) have used the halogen oven to dry some vegetables and fruits. Klunzinger's mullet Planiliza klunzingeri is a member of the Mugilidae family with 79 valid species around world (Fricke et al., 2020), including nine species and four genera which are Ellochelon, Mugil, Osteomugil and Planiliza in Iraq (Ali et al., 2018), with three species (P. klunzingeri, $P$. subviridis, Osteomugil speigleri) most common in Iraqi marine waters (Mohamed et al., 2016); All mugilid fishes are live in and temperate seas. Chiefly marine (coastal) and brackish water; some in freshwater (Planliza $a b u$ only is live in fresh and estuaries) (Froese \& Pauly, 2019).

There are no published literatures in Iraq on drying fish by halogen energy. Therefore, the parameters of kinetic drying and effect of drying temperature on the qualitative characteristics of dried fish using halogen energy is un known. Moreover, Fish Klunzinger's mullet Planiliza klunzingeri are abundant in Basrah province, and they are highly perishable, therefore the study aimed to investigate the drying of Klunzinger's mullet fish using halogen dryer and study it is effect on the microbial and chemical 
properties of dried fish at different drying temperatures and storage periods. In addition,

\section{Materials \& Methods}

Klunzinger's mullet Planiliza klunzingeri was obtained from local markets in Basrah province, with a weight of $200 \mathrm{~g}$ and a length of $20 \mathrm{~cm}$. The samples were transported in a refrigerated container to the food engineering laboratory in Department of Food Sciences. The fish were washed by tap water, beheaded and opened from the ventral side as well as the internal organs and glands were removed. Some of the fish were unsalted and the others were salted with concentration of $10 \% \mathrm{NaCl}$ then left for 30 minutes at room temperature to remove the maximum amount of moisture. After that, fish was weighed and dried by halogen dryer (A digital halogen dryer made of HE. House Co.). It consists of a Pyrex container of 12 L capacity, glass cover provided with halogen lamp (1300 W power) as a heat source and fan with speed of 1500 rpm. Mercury thermometer was used to measure the temperature. The drying was done at five temperatures of $60,65,70,75$ and $80{ }^{\circ} \mathrm{C}$ and the weight was measured after every 10 minutes of the drying process. The moisture content ( $g$ water) based on the dry weight (moisture content on dry weight=moisture content \%100-moisture content \%) that was used. All the experiments in the present study were conducted in triplicates.

Drying rate was calculated as follows (Toledo, 2007):

$$
D R=\frac{M_{t+d_{t}}-M_{t}}{d_{t}}
$$

Where $\mathrm{M}_{\mathrm{t}}$ is moisture content at $\mathrm{t}$ and $\mathrm{M}_{\mathrm{t}}+\mathrm{d}_{\mathrm{t}}$ is the moisture content at $\mathrm{t}+\mathrm{dt}, d_{t}$ Is the drying time (min.) using artificial neural network to predict the moisture content.

The drying efficiency is calculated from the following equation (Toledo, 2007).

$$
\eta=\frac{T_{d}-T_{\text {out }}}{T_{d}-T_{a}} \times 100
$$

Where $T_{d}$ is the drying air temperature, $T_{\text {out }}$ is the out let air temperature from the dryer and $\mathrm{T}_{\mathrm{a}}$ is the ambient air temperature. After the drying process, the dried fish were placed in vacuumed polyethylene bags and stored at laboratory temperature $\left(25^{\circ} \mathrm{C}\right)$ for $0,7,14,21$, 28 and 35 days, that was for fresh and dried samples during the storage periods.

\section{Drying mechanism using infrared dryer}

The fish were placed on the perforated tray inside the halogen dryer and the temperature required for drying was determined. When operating the halogen dryer, the halogen lamp emits infrared radiation and at the same time the air inside the dryer gets circulated by the fan. Infrared radiation falls on the surface of the fish and thus heat the fish as a result of heat transfer by radiation and conduction. The reason for heating is that vibrations occur in water molecules which their frequency matches the infrared frequency. Then the moisture evaporates from fish.

\section{Che mical tests:}

The chemical composition of fresh and dried salted and unsalted fish was studied. The percentage of moisture was estimated by using an electric oven at $105{ }^{\circ} \mathrm{C}$ until weight stability. Protein was estimated by the method of Semi-micro Kjeldahl . The total nitrogen was estimated and multiplied by the protein conversion factor (6.25). Fat percentage was estimated by the Soxhlet method using organic solvent petroleum ether with a boiling point range between $40-60{ }^{\circ} \mathrm{C}$. Ash was determined 
via burn the fish sample in the Muffle furnace at $550{ }^{\circ} \mathrm{C}$ in order to get the white ash (Egan et al., 1988).

\section{Chemical indices}

The $\mathrm{pH}$ meter (Jenway 3505, Bibby Scientific Ltd., England) was used to measure $\mathrm{pH}$ of fish samples. $10 \mathrm{~g}$ of fish samples were homogenized in $100 \mathrm{ml}$ of distilled water for 30 s (Rossini et al., 2009).

The thiobarbituric acid number (TBA) was estimated according to Egan et al. (1988). 10 $\mathrm{g}$ of fish samples were mixed with $50 \mathrm{~mL}$ of distilled water in a $250 \mathrm{ml}$ beaker. After that, $\mathrm{pH}$ was adjusted to $1.5 \mathrm{using} 2.5 \mathrm{ml}$ of $4 \mathrm{~N}$ HCL. $5 \mathrm{ml}$ of TBA solution was prepared by dissolving $0.2883 \mathrm{~g}$ of TBA reagents in 100 $\mathrm{ml}$ of glacial $90\left(\% \mathrm{v} \cdot \mathrm{v}^{-1}\right)$ acetic acid. Next, the mixture was sealed, heated and then cooled to room temperature. The absorbance (D) of samples along with the blank sample (a mixture of $5 \mathrm{ml}$ of distilled water with $5 \mathrm{ml}$ of the TBA reagents) was measured at a wavelength of $538 \quad \mathrm{~nm}$ using spectrophotometer. The value is expressed in (mg kg oil ${ }^{-1}$ ). The TBA value of samples was calculated from the following Equation:

TBA $\left(\mathrm{mg} \mathrm{kg} \mathrm{oil}^{-1}\right)=7.8 \times \mathrm{D}$,

where 7.8 is constant.

\section{Microbial tests}

Microbiological tests were performed under hygiene and sterilized conditions. A $10 \mathrm{~g}$ was weighed from different fish samples and 90 $\mathrm{ml}$ of sterile dilution solution $(0.1 \%$ peptone $)$ was added under sterile conditions then the samples were mixed well. A series of dilutions was performed under sterile conditions. The dish casting method was used for the cultured process. The microbial counts were expressed in the unit. Total counts of bacteria were estimated using Nutrient Agar and incubated at $32^{\circ} \mathrm{C}$ for $24-48$ hours. Total coliform bacteria were estimated using MacConkey agar and incubated at $37^{\circ} \mathrm{C}$ for 24-48 hours. Staphylococcus aureus was estimated using Mannitol salt Agar and incubated at $32{ }^{\circ} \mathrm{C}$ for 48 hours, while the estimation of yeasts and molds was achieved by Potato Dextrose Agar and incubated at 25 ${ }^{\circ} \mathrm{C}$ temperature for 24-96 hours. Andrews's method was followed to detect Salmonella after activation by Tetrathionata broth for 24 hours at a temperature of $35^{\circ} \mathrm{C}$ then cultured on the Salmonella Shigella Agar media and incubated at $37^{\circ} \mathrm{C}$ temperature for $24-48$ hours (Andrews, 1992).

\section{Rehydration}

The rehydration process of dried samples was calculated. A $2 \mathrm{~g}$ from dried salted and unsalted fish was taken and placed in a flask $(500 \mathrm{ml})$, then $80 \mathrm{ml}$ of distilled water at a temperature of $30{ }^{\circ} \mathrm{C}$ was added. The flask was covered by a piece of glass and then boiled for 15 minutes using a heater. After that, the sample was left for 2 hours at room temperature of $25^{\circ} \mathrm{C}$. The excess water was filtered by a Buechner funnel using Whatman NO.4 filter paper. The duration of filtration was for one minute. The rehydrated samples were taken from the funnel and weighted. The rehydration was calculated from equation (3) (Rangana, 1976):

$$
\mathrm{Re}=\frac{\mathrm{W}_{\mathrm{r}}}{\mathrm{W}_{\mathrm{ad}}} \times 100
$$

Where $\mathrm{W}_{\mathrm{r}}$ is the dried sample weight after rehydration and $\mathrm{W}_{\mathrm{ad}}$ is the dried sample weight before rehydration (after drying).

\section{Mathe matical modeling}


Al- Rubaiy et al. / Basrah J. Agric. Sci., 33(1): 231- 260, 2020

The reactions that occur in foods during storage have two models, the first is called between the $\mathrm{pH}$ and the reaction time $(\mathrm{t})$ which is represented by the general equations (4) and (5) (Özilgen, 1998):

$$
\begin{gathered}
\frac{d(p H)}{d t}=-k_{0} \\
p H=p H_{o}-k_{0} t
\end{gathered}
$$

Another order is the first order reaction, represented by equations (6) and (7):

$$
\begin{gathered}
\frac{d(p H)}{d t}=-k_{1}(p H) \\
\ln (p H)=\ln \left(p H_{o}\right)-k_{1} t
\end{gathered}
$$

Where, $p H$ is the potential hydrogen at given of storage time, $p H_{o}$ is the initial potential hydrogen, $\mathrm{k}_{0}$ is the rate constant of the zero order model $(1 / \mathrm{h})$ and $\mathrm{k}_{1}$ is the rate constant of the first order model $(1 / \mathrm{h})$.

The modeling process was performed using Excel 2016 by solver to find the constant $\mathrm{k}$ and predict theoretical values of $\mathrm{pH}$ based on the determination coefficient $\left(\mathrm{R}^{2}\right)$, the chi square $\left(\mathrm{x}^{2}\right)$ and the root mean square error (RMSE) which were calculated from the following equations:

$$
R^{2}=\frac{\sum_{i=1}^{N}\left(p H_{t h .}-\overline{p H_{t h .}}\right)^{2}}{\sum_{i=1}^{n}\left(p H_{\text {exp.. }}-\overline{p H_{\text {exp. }}}\right)^{2}}
$$

zero-order reaction, i.e. a linear relationship

$$
x^{2}=\frac{\sum_{i=1}^{N}\left(p H_{\text {exp. }}-p H_{t h .}\right)^{2}}{N-n}
$$

$$
R M S E=\left[\frac{\sum_{i=1}^{N}\left(p H_{\text {exp. }}-p H_{t h .}\right)^{2}}{N}\right]^{1 / 2}
$$

\section{Statistical analysis}

The complete random design (C.R.D.) with factorial experiment $(2 \times 5 \times 7)$, was used. The treatments were salted and unsalted fish, five drying temperatures and seven storage periods. The data were analyzed statistically using the statistical program SPSS ver. 21. The comparison among means was conducted by using less significant difference (L.S.D.) at 0.05 level.

\section{Artificial neural network (ANN) modeling} Multilayered perception artificial neural network was applied for prediction of moisture content (neuron output layer) and three neurons input layer (drying time and drying temperature) was used. SPSS Ver. 21 software was used in this study. Forward Back Propagation network was implemented to perform suitable answer. Training process is a repetitive process contained the changes of weights between different layers where during training gradually reaches to stability of these weights, and the error occurred between the experimental and the predicted quantities were minimum. The optimized conditions was found by using activation function (hyperbolic tangent function) as given in equation (11) (Hernandez-Perez et al., 2004):

$$
Y_{j}=\frac{2}{\left(1+\exp \left(-2 X_{j}\right)\right)}-1
$$


Where, $Y_{j}$ is the output, $X_{j}$ is the sum weigh inputs of every neurons of layer $j$.

$X_{j}$ was calculated according to equation (12):

$$
X_{j}=\sum_{i=1}^{m} W_{i j} \times Y_{i}+b_{j}
$$

Where $m$ is the output layer neurons number, $W_{i j}$ is the weight between layers $i$ and $j, Y_{i}$ is the neuron $i$ output and $b_{j}$ is the bias amount of layer $j$ neuron. $52.3 \%$ of data for training and $16.8 \%$ for testing. To obtain a network with an appropriate topology by applying training algorithms, sum of square error (SSE) term was used to get minimized error. As well as determination of the important of the independent variables (drying time and drying temperature). Architecture of the artificial network used in modelling for moisture content is illustrated in fig. (1).

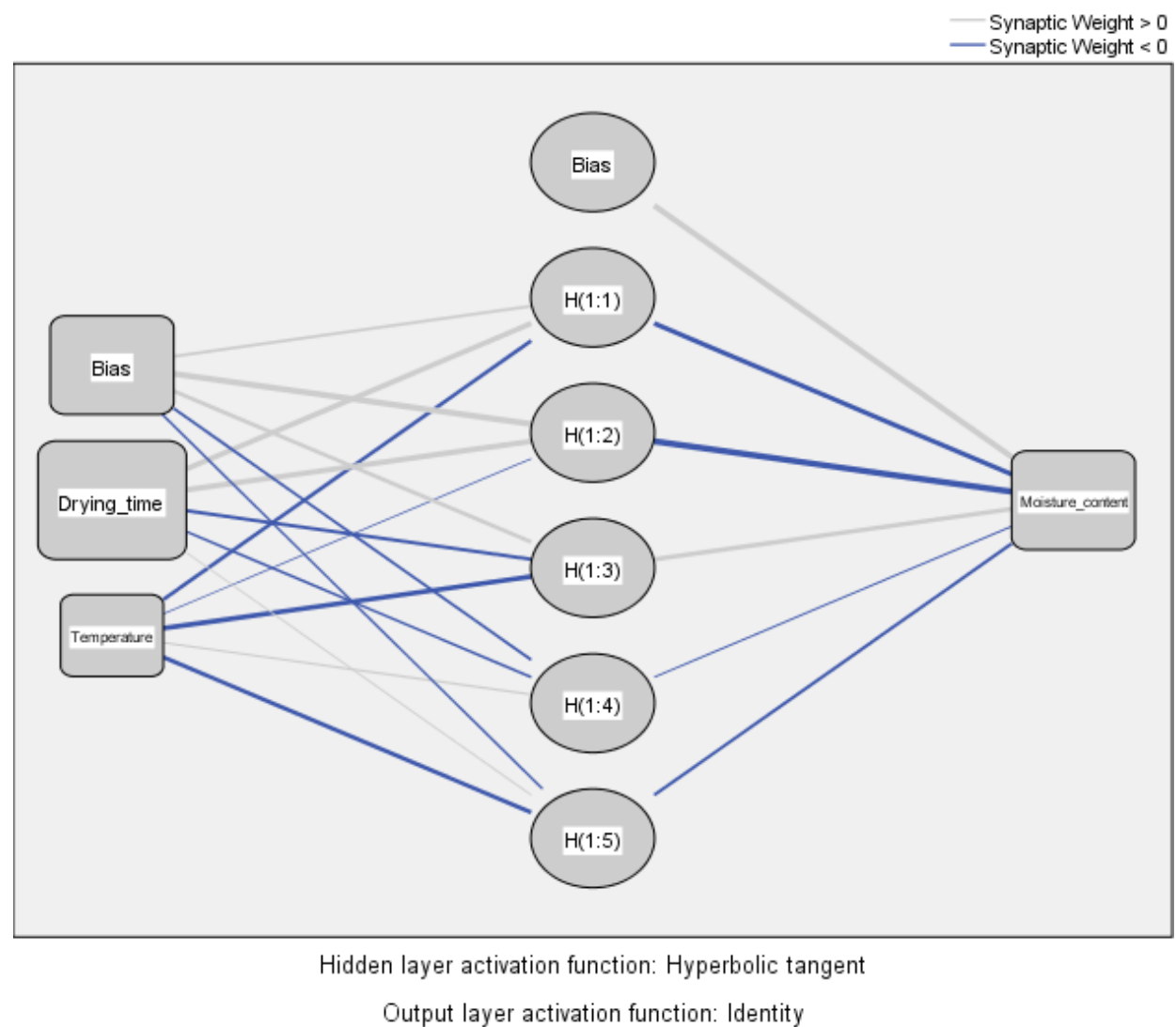

Fig. (1): Architecture of the artificial network used in modelling for moisture content.

\section{Results \& Discussion:}

\section{Moisture content}

Figs.(2) and (3) showed the drying curve of Klunzinger's mullet (salted and unsalted) with different temperatures $(60,65,70,75$ and $80^{\circ} \mathrm{C}$ ). The results showed that the moisture content in all samples gradually decreased significantly $(\mathrm{P}<0.05)$ with increasing drying time at different temperatures. The moisture content decreased from 3.23 (g water. (g d.b. 1) (d.b. means dry basis)in fresh fish to 0.28 ( $g$ water. (g d.b. ${ }^{-1}$ ) in salted dried fish after 220 minutes of drying process using $60^{\circ} \mathrm{C}$ temperature. Also, the time required for 
drying fish was 180 and 210 minutes at 70 and $80{ }^{\circ} \mathrm{C}$ temperature respectively. In this case, the moisture content decreased to 0.25 and 0.24 (g water. (g d.b. ${ }^{-1}$ ) respectively. As for unsalted fish, the moisture content decreased further and took longer time. The moisture content in fresh fish was decreased from 3.33 (g water. $\left(\mathrm{g}\right.$ d.b. ${ }^{-1}$ ) to 0.25 (g water. (g d.b. ${ }^{-1}$ ) after 250 minutes of drying time by using $60{ }^{\circ} \mathrm{C}$ temperature for salted fish. In addition, it required 180 and 210 minutes at 70 and $80{ }^{\circ} \mathrm{C}$ temperature respectively. The moisture content decreased to 0.25 (g water. (g d.b. ${ }^{-1}$ ) for both temperatures. The reason of the variation in moisture content was due to the high temperature and the duration of exposure. Increasing temperature led to ionize the water molecules and increase their movement, which in turn led to generate thermal energy, which caused an increase in the vapor pressure inside the foodstuffs, and that leads to the evaporation of moisture faster with increasing temperature (Patir et al., 2006). This process occurred at a temperature of $80^{\circ} \mathrm{C}$, which reduced the drying time by 70 minutes compared with 60 and $70{ }^{\circ} \mathrm{C}$ temperatures. The results showed that the drying process of salted fish was faster than the unsalted fish. This may be attributed to the salt which draws internal moisture out of the fish meat and transfers it to the surface of the fish, for evaporation. The use of halogen dryer in the drying process gave a high drying efficiency, because of halogen energy (infrared energy) and movement of air, which prevented fish surface hardness during the drying process compared with conventional drying, which depends on the high temperature only whether it is an electric dryer or a natural sun drying. Kumar (2015) and Al-Temimi (2018) indicated that the moisture content of fish carp was reduced with an increase of the energy levels when the microwave dryer was used, which led to reduce the drying time. Lithi et al. (2020) stated that the moisture content of fish was decreased from $80.71 \%$ to $7.5 \%$ by using solar dryer and reduced to $7.86 \%$ using open sun drying. Tanuja et al. (2020) disclosed that the moisture content of the fish (Stolephorus commersonii) reduced from $81.97 \%$ to $28.87 \%$ and $34.43 \%$ by the solar rack dryer and natural sun drying respectively.

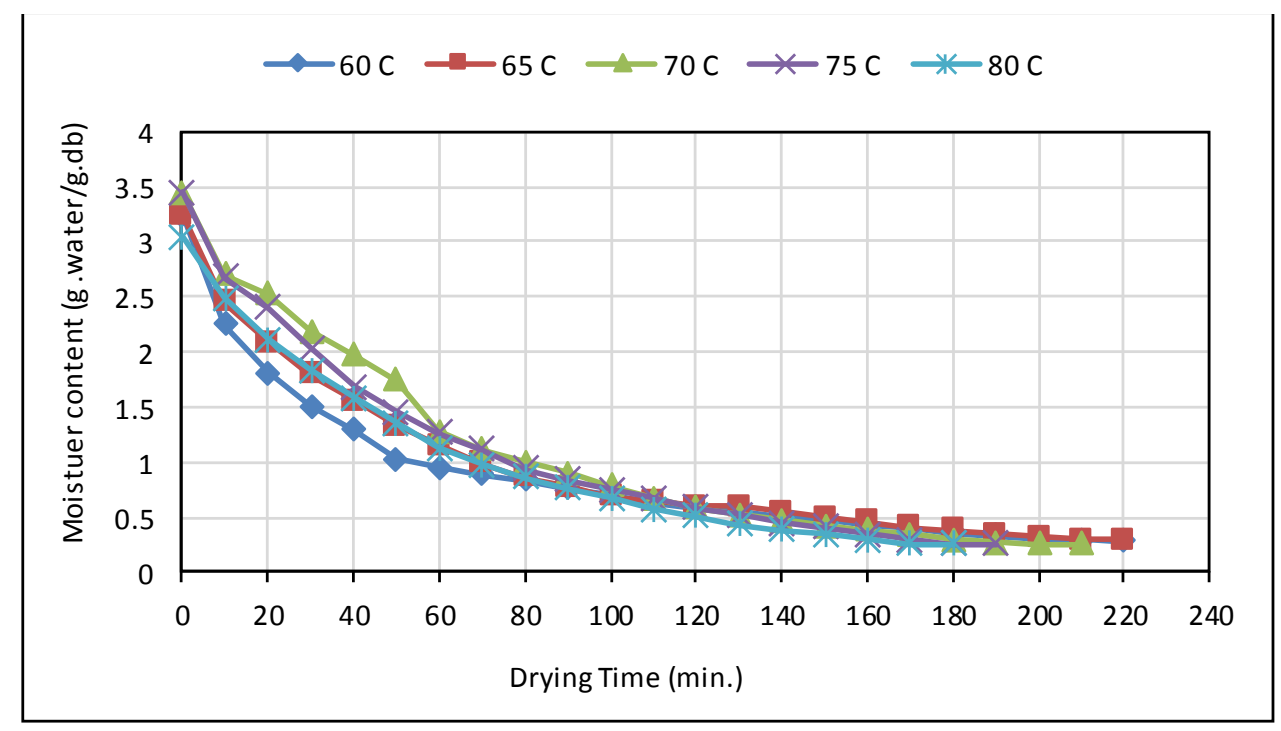

Fig. (2): The drying curve of salted Klunzinger's mullet at different tempe ratures. 
Al- Rubaiy et al. / Basrah J. Agric. Sci., 33(1): 231- 260, 2020

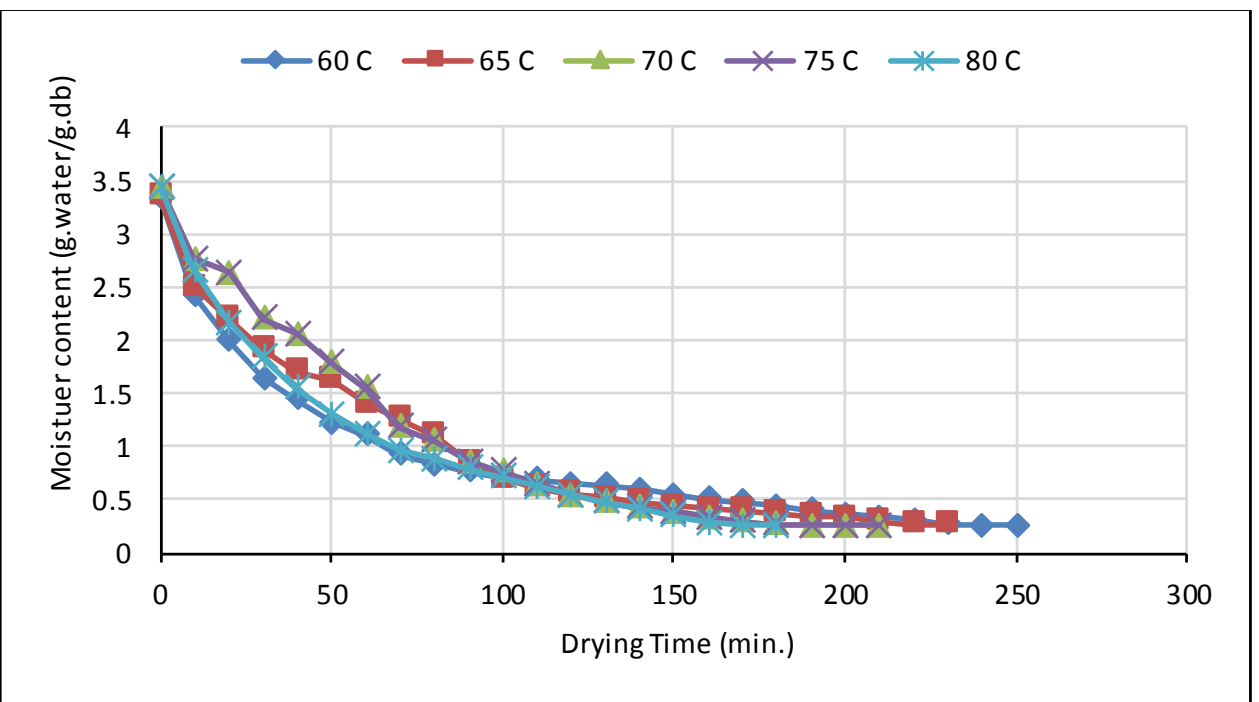

Fig. (3): The drying curve of unsalted Klunzinger's mullet at different temperatures.

\section{Drying Rate:}

Figs. (4) and (5) showed the drying rate curve for dried salted and unsalted Klunzinger's mullet at different temperatures $(60,65,70,75$ and $\left.80^{\circ} \mathrm{C}\right)$. The results showed that the drying rate in all samples significantly $(\mathrm{P}<0.05)$ decreased with increasing drying time at different temperatures. The drying rate decreased from 0.099 ( $\mathrm{g}$ water. $\left.\mathrm{min}^{-1}\right)$ for fresh fish to 0.0001 ( $\mathrm{g}$ water. $\mathrm{min}^{-1}$ ) after $220 \mathrm{~min}$. of drying process at $60{ }^{\circ} \mathrm{C}$ for salted fish. Drying rate reached 0.0025 and 0.0006 (g water. $\min ^{-1}$ ) when drying time was 180 and $210 \mathrm{~min}$. at 70 and $80{ }^{\circ} \mathrm{C}$ respectively. For unsalted fish, the drying rate decreased from 0.090 (g water. $\left.\mathrm{min}^{-1}\right)$ to $0.000518 \quad(\mathrm{~g}$ water. $\mathrm{min}^{-1}$ ) for fresh fish after $250 \mathrm{~min}$. of drying process at $60^{\circ} \mathrm{C}$ temperature for unsalted fish and it required 180 and $210 \mathrm{~min}$. at 70 and $80{ }^{\circ} \mathrm{C}$ temperature. The reason for the variation in drying rate was due to the water in the foodstuffs that is affected by the high temperature and the duration of exposure. Al-Temimi (2018) used the microwave for drying carp fish and found that the drying rate decreased as energy levels increased.

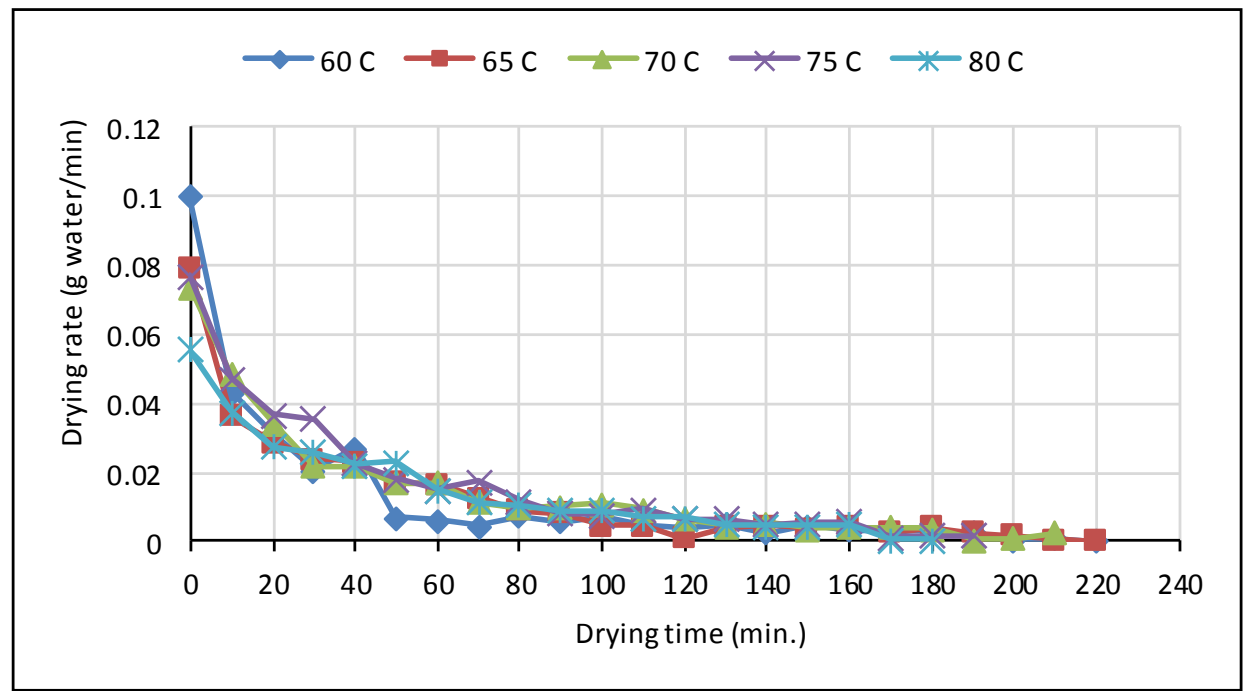

Fig. (4): The drying rate curve of salted Klunzinger's mullet at diffe rent te mperatures. 
Al- Rubaiy et al. / Basrah J. Agric. Sci., 33(1): 231- 260, 2020

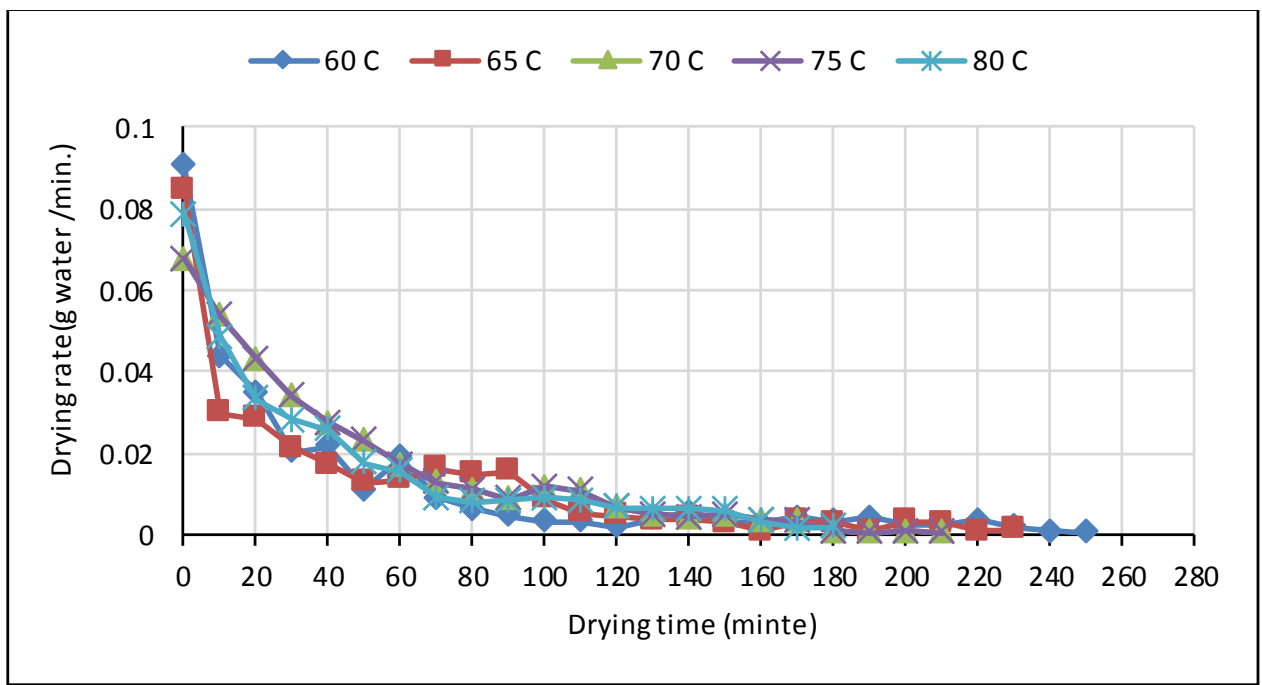

Fig. (5): The drying rate curve of unsalted Klunzinger's mullet at different tempe ratures.

Lim et al. (2020) stated that superheated steam drying produces a significant shorter drying time because of the drying rates were higher.

\section{Drying efficiency}

Fig. (6) showed the drying efficiency of the dried fish using halogen dryer at different temperatures. The results showed that drying efficiency decreased as drying temperature increased because of increase of the heat loss and output air temperature from dryer. The drying efficiency decreased from $71.36 \%$ to
$68.74 \%$ when drying temperature increased from $65^{\circ} \mathrm{C}$ to $80^{\circ} \mathrm{C}$ respectively. The relationship between drying efficiency and drying temperature was linear as presented in equation (13):

$$
\begin{gathered}
\eta=-0.1328 T+79.292 ; R^{2} \\
=0.9449
\end{gathered}
$$

Al-Hilphy \& Al-Rikabi (2013) found that the drying efficiency of strawberry by halogen dryer decreased with the increase of drying temperature, and the some researchers

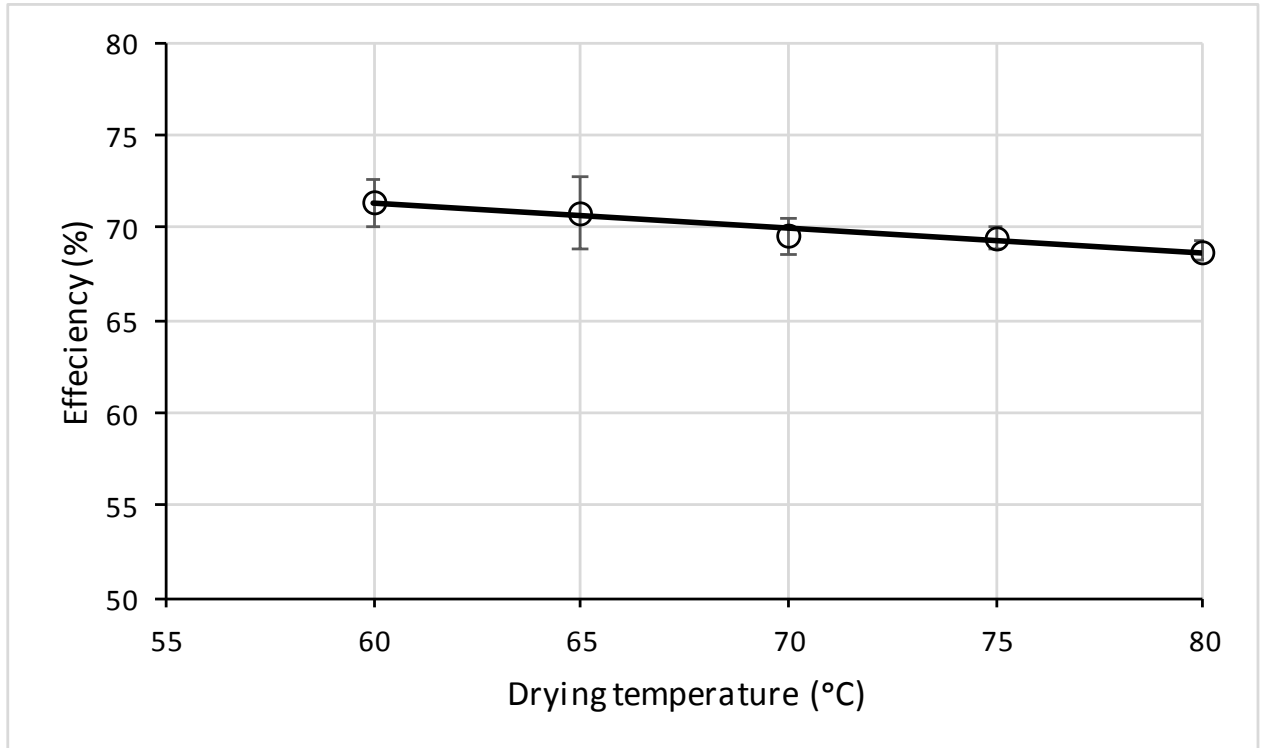

Fig. (6): The drying efficiency of dried Klunzinger's mullet at different temperatures. 


\section{Al- Rubaiy et al. / Basrah J. Agric. Sci., 33(1): 231- 260, 2020}

found that the relationship between drying efficiency and drying temperature was polynomial. The differences between the current study and other studies it may attributed to use various dryers i.e., the current study used halogen dryer, but the other studies used hot air dryers.

\section{Chemical Content:}

The results showed that there are significant changes $(\mathrm{P}<0.05)$ in the chemical content of dried salted and unsalted Klunzinger's mullet at different temperatures of $60,65,70,75$ and $\left.80{ }^{\circ} \mathrm{C}\right)$ during storage periods $(0,7,14,21,28$ and 35) days. The results showed that the chemical content of fresh fish was 76.4, 17.4, 4.68 and $1.52 \%$ for moisture, protein, fat and ash respectively. The results agreed with AlBayati \& Ahmed (2008) who estimated the chemical composition of fresh Biayah fish, which was 76.6, 18.70, 2.70 and $1.50 \%$ respectively. The variation in the percentages of chemical contents was due to different fishing times, feeding and fish age. The results illustrated that there were a significantly decrease $(\mathrm{P}<0.05)$ in the moisture content for all samples with increasing drying temperatures and that unlike in the other chemical composition percentages. These results were consistent with Al-Shatty et al. (2014) and Al-Temimi (2018) who stated that the moisture content decreased, and the other chemical composition percentage increased.

Table (1) showed that the moisture content (based on wet basis \%) significantly decreased $(\mathrm{P}<0.05)$ with increasing drying periods at different temperatures for all samples. The results depicted that the moisture content decreased from $76.94 \%$ in fresh Klunzinger's mullet to 22.89, 22.62, 20.22, 19.93 and $19.93 \%$ for dried salted fish using 60, 65, 70, 75 and $80{ }^{\circ} \mathrm{C}$ temperatures respectively, whereas, for dried unsalted fish at the same temperatures, they were 20.18, $20.18,20.18,20.18$ and $20.12 \%$ respectively at zero-day of storage periods. The results were agreed with Al-Shatty et al. (2014) who observed that the moisture content of fresh carp fish was $79.50 \%$ and decreased to 22.85 $\%$ using the electric dryer. The results showed that the moisture content slightly increased during the storage period. This is due to the difference in moisture content between fish meat and its surrounding which has a little moist air, as well as the moisture content in the outside air, as the packaging bags may be permeable to moisture, which led to different molecular pressures and then the moisture transferred from the outside air to the fish. Majeed \& Al-Hilphy (2007) stated that the moisture can be transferred from ambient to unpackaged dried fish. The results were not consistent with Al-Fadhly (2009) who confirmed that the moisture content stayed low after drying process of fish and during increasing the storage periods. Also, table (1) showed that the protein content significantly increased $(\mathrm{P}<0.05)$ with drying temperatures, i. e., The percentage of protein increased from $17.4 \%$ in fresh Klunzinger's mullet to 55.30, $56.11,59.20,61.45$ and $60.24 \%$ for dried salted fish at $60,65,70,75$ and $80{ }^{\circ} \mathrm{C}$ temperatures respectively, whereas, for dried unsalted fish at the same temperatures, they were reached 59.77, 60.10, 59.11, 61.65 and $60.18 \%$ at zero day of storage periods. The reason for this variation in the protein content may be due to heat which led to denaturing protein, which reduced its portability of water (Patir et al., 2006). Azam, et al. (2003) who studied drying Mugil cephalus, the researchers found that protein levels increased in summer to $68.09 \%$ and more than winter $(60.58 \%)$. Also, the results agreed with AlFadhly (2009) who stated that protein content 


\section{Al- Rubaiy et al. / Basrah J. Agric. Sci., 33(1): 231- 260, 2020}

increased after the decreasing moisture for salted and sun-dried fish. The results showed a decrease in protein content for dried salted and unsalted fish with an increase of the storage periods, due to a slight increase in moisture during the storage periods. The results were agreed with El-Sebaiy \& Metwalli (1989) who found that protein content decreased from $82.50 \%$ to $71.10 \%$ in small mullet meat. The reason may be due to the different types of fish, different ways and environmental conditions in fishing, as well as, the salt concentration used. These results were agreed with Al-Temimi (2018) who found a low protein content in microwaved dried carp fish during the storage periods.

Table (1) showed that the fat content significantly increased $(\mathrm{P}<0.05)$ with the drying temperatures. The percentage of fat increased from $4.68 \%$ in fresh Klunzinger's mullet to $15.46,15.34,15.50,14.82$ and 14.22 $\%$ for dried salted fish at $60,65,70,75$ and $80^{\circ} \mathrm{C}$ temperature respectively, and for dried unsalted fish were 15.46, 13.93, 15.42, 14.50 and $14.34 \%$ respectively at zero day of storage periods. This variation in fat content may be due to the decrease of moisture because of the drying process has effected on the chemical content of the fish. The results agreed with Azam et al. (2003) who studied of dried Biayah fish and noted that the percentage of fat in the summer increased to $8.22 \%$ and decrease to $4.87 \%$. Also, the results agreed with Al-Shatty et al. (2014) who showed that fat percentage was increased after decreasing moisture of dried salted fish using sun drying. Tanuja et al. (2020) declared that the fat content of dried Anchovy (S. commersonii) was $3.22 \%$ and $4.31 \%$ using open sun drying and solar dryer respectively. The results disclosed a decrease in fat content for dried salted and unsalted fish with an increase in the storage periods, due to a slight increase in moisture during the storage periods. The results were agreed with El-Sebaiy \& Metwalli (1989) who showed that the percentage of fat for dried fish Puntius sp. (stored for 135 days) was decreased from $25.12 \%$ to $20.90 \%$. These results were agreed with Al-Temimi (2018) who found a low-fat content in microwave dried carp fish during the storage species. This may be due to the ability of dried fish to absorb moisture from the atmosphere, which directly effects on the chemical composition of dried fish. Table (1) illustrated that the ash content significantly increased $(\mathrm{P}<0.05)$ with the drying temperatures. The percentage of ash increased from $1.52 \%$ in fresh Klunzinger's mullet to $6.35,5.93,5.05,3.75$ and $5.60 \%$ for dried salted fish at 60, 65, 70, 75 and $80{ }^{\circ} \mathrm{C}$ temperatures, and for dried unsalted fish at the same temperatures was $6.12,5.61,5.29,3.67$ and $5.36 \%$ respectively at zero day of storage periods. This variation in ash content is due to the decrease of moisture which caused by drying and salting process. The results agreed with Azam, et al. (2003) who studied dried Biayah fish, and explained that the ash content increased in summer to $10.35 \%$, and in winter reached $7.45 \%$. Also, agreed with Al-Shatty et al. (2014) who showed an increase in the percentage of ash after decreasing moisture of dried salted fish by sun drying. The results showed a decrease in ash content for dried salted and unsalted fish with an increase in the storage periods, this was due to a slight increase in moisture during the storage periods. The results agreed with El-Sebaiy \& Metwalli (1989) who found that the percentage of ash for dried fish Puntius sp. (stored for 135 days) decreased. The reason may be due to the different types of fish, the different methods and environmental conditions in fishing, as well as the salt 
Al- Rubaiy et al. / Basrah J. Agric. Sci., 33(1): 231- 260, 2020

Table (1): Chemical composition of drie d salted and unsalted Klunzinge r's mullet at different tempe ratures during storage pe riods.

\begin{tabular}{|c|c|c|c|c|c|c|c|c|c|}
\hline \multirow{2}{*}{$\begin{array}{c}\text { Temperature } \\
\left({ }^{\circ} \mathrm{C}\right)\end{array}$} & \multirow{2}{*}{$\begin{array}{l}\text { Storage periods } \\
\text { (day) }\end{array}$} & \multicolumn{4}{|c|}{ Dried salted Klunzinger's mullet } & \multicolumn{4}{|c|}{ Dried unsalted Klunzinger's mullet } \\
\hline & & Moisture & Protein & Fat & Ash & Moisture & protein & Fat & Ash \\
\hline \multirow{6}{*}{60} & 0 & $0.20 \pm 22.89$ & $55.30 \pm 0.30$ & $15.46 \pm 0.22$ & $6.35 \pm 0.10$ & $20.18 \pm 0.20$ & $59.77 \pm 0.31$ & $13.83 \pm 0.21$ & $6.12 \pm 0.08$ \\
\hline & 7 & $23.19 \pm 0.18$ & $55.30 \pm 0.30$ & $15.45 \pm 0.21$ & $6.06 \pm 0.07$ & $20.47 \pm 0.21$ & $59.67 \pm 0.29$ & $13.92 \pm 0.21$ & $5.94 \pm 0.10$ \\
\hline & 14 & $20.48 \pm 0.21$ & $55.28 \pm 0.27$ & $15.40 \pm 0.20$ & $5.96 \pm 0.07$ & $20.69 \pm 0.19$ & $59.84 \pm 0.31$ & $13.90 \pm 0.21$ & $5.93 \pm 0.09$ \\
\hline & 21 & $23.65 \pm 0.18$ & $55.17 \pm 0.26$ & $15.33 \pm 0.18$ & $5.85 \pm 0,06$ & $20.78 \pm 0.20$ & $59.41 \pm 0.30$ & $13.88 \pm 0.20$ & $5.93 \pm 0.09$ \\
\hline & 28 & $23.77 \pm 0.20$ & $55.10 \pm 0.26$ & $15.30 \pm 0.18$ & $5.83 \pm 0,05$ & $20.92 \pm 0.21$ & $59.35 \pm 0.29$ & $13.82 \pm 0.20$ & $5.91 \pm 0.10$ \\
\hline & 35 & $24.19 \pm 0.19$ & $55.00 \pm 0.25$ & $15.00 \pm 0.19$ & $5.81 \pm 0.05$ & $21.22 \pm 0.22$ & $59.30 \pm 0.28$ & $13.80 \pm 0.19$ & $5,68 \pm 0.11$ \\
\hline \multirow{6}{*}{65} & 0 & $22.62 \pm 0.20$ & $56.11 \pm 0.31$ & $15.34 \pm 0.21$ & $5.93 \pm 0.06$ & $20.18 \pm 0.19$ & $60.10 \pm 0.32$ & $13.93 \pm 0.20$ & $5.61 \pm 0.11$ \\
\hline & 7 & $22.77 \pm 0.18$ & $56.08 \pm 0.30$ & $15.28 \pm 0.20$ & $5.87 \pm 0.07$ & $20.48 \pm 0.18$ & $59.96 \pm 0.31$ & $13.92 \pm 0.21$ & $5.48 \pm 0.09$ \\
\hline & 14 & $22.93 \pm 0.18$ & $56.01 \pm 0.31$ & $15.24 \pm 0.19$ & $5.82 \pm 0.05$ & $20.70 \pm 0.19$ & $59.95 \pm 0.31$ & $13.90 \pm 0.21$ & $5.29 \pm 0.10$ \\
\hline & 21 & $23.11 \pm 0.21$ & $55.92 \pm 0.32$ & $15.18 \pm 0.18$ & $5.79 \pm 0.05$ & $20.92 \pm 0.21$ & $59.88 \pm 0.30$ & $13.88 \pm 0.20$ & $5.17 \pm 0.09$ \\
\hline & 28 & $23.56 \pm 0.20$ & $55.88 \pm 0.31$ & $15.14 \pm 0.19$ & $5.45 \pm 0.06$ & $21.13 \pm 0.19$ & $59.82 \pm 0.29$ & $13.82 \pm 0.20$ & $5.07 \pm 0.09$ \\
\hline & 35 & $23.80 \pm 0.21$ & $55.80 \pm 0.29$ & $15.11 \pm 0.20$ & $5.29 \pm 0.07$ & $21.22 \pm 0.20$ & $59.77 \pm 0.30$ & $13.80 \pm 0.21$ & $5.04 \pm 0.10$ \\
\hline \multirow{6}{*}{70} & 0 & $20.22 \pm 0.19$ & $59.20 \pm 0.31$ & $15.53 \pm 0.22$ & $5.05 \pm 0.06$ & $20.18 \pm 0.19$ & $59.11 \pm 0.28$ & $15.42 \pm 0.22$ & $5.29 \pm 0.12$ \\
\hline & 7 & $20.43 \pm 0.19$ & $59.16 \pm 0.31$ & $15.50 \pm 0.22$ & $4.91 \pm 0.05$ & $20.45 \pm 0.21$ & $58.08 \pm 0.28$ & $15.36 \pm 0.21$ & $5.11 \pm 0.09$ \\
\hline & 14 & $20.76 \pm 0.20$ & $59.14 \pm 0.29$ & $15.46 \pm 0.21$ & $4.64 \pm 0.05$ & $20.71 \pm 0.20$ & $58.94 \pm 0.29$ & $15.32 \pm 0.20$ & $5.03 \pm 0.10$ \\
\hline & 21 & $20.84 \pm 0.19$ & $59.14 \pm 0.29$ & $15.43 \pm 0.20$ & $4.60 \pm 0.06$ & $20.96 \pm 0.22$ & $58.88 \pm 0.30$ & $15.28 \pm 0.19$ & $4.88 \pm 0.08$ \\
\hline & 28 & $21.05 \pm 0.18$ & $59.10 \pm 0.28$ & $15.40 \pm 0.20$ & $4.45 \pm 0.05$ & $21.24 \pm 0.22$ & $59.82 \pm 0.30$ & $15.20 \pm 0.18$ & $4.84 \pm 0.08$ \\
\hline & 35 & $21.31 \pm 0.18$ & $55.80 \pm 0.28$ & $15.38 \pm 0.19$ & $4.38 \pm 0.07$ & $21.57 \pm 0.20$ & $58.61 \pm 0.29$ & $15.18 \pm 0.18$ & $4.59 \pm 0.08$ \\
\hline \multirow{6}{*}{75} & 0 & $19.93 \pm 0.19$ & $61.45 \pm 0.32$ & $14.87 \pm 0.16$ & $3.75 \pm 0.08$ & $20.18 \pm 0.21$ & $61.65 \pm 0.32$ & $14.50 \pm 0.16$ & $3.67 \pm 0.11$ \\
\hline & 7 & $20.11 \pm 0.18$ & $61.40 \pm 0.31$ & $14.82 \pm 0.16$ & $3.67 \pm 0.08$ & $20.49 \pm 0.19$ & $61.45 \pm 0.32$ & $14.45 \pm 0.16$ & $3.61 \pm 0.11$ \\
\hline & 14 & $20.34 \pm 0.20$ & $61.22 \pm 0.31$ & $14.78 \pm 0.17$ & $3.66 \pm 0.07$ & $20.85 \pm 0.19$ & $61.34 \pm 0.31$ & $14.26 \pm 0.15$ & $3.55 \pm 0.12$ \\
\hline & 21 & $20.55 \pm 0.19$ & $59.13 \pm 0.29$ & $14.76 \pm 0.17$ & $3.53 \pm 0.07$ & $21.11 \pm 0.20$ & $61.22 \pm 0.30$ & $14.11 \pm 0.15$ & $3.45 \pm 0.10$ \\
\hline & 28 & $20.76 \pm 0.21$ & $61.00 \pm 0.33$ & $14.67 \pm 0.16$ & $3.46 \pm 0.08$ & $21.43 \pm 0.21$ & $61.11 \pm 0.31$ & $14.08 \pm 0.15$ & $3.38 \pm 0.09$ \\
\hline & 35 & $20.92 \pm 0.21$ & $60.97 \pm 0.34$ & $14.65 \pm 0.16$ & $3.46 \pm 0.08$ & $21.57 \pm 0.21$ & $61.08 \pm 0.31$ & $14.00 \pm 0.20$ & $3.35 \pm 0.08$ \\
\hline \multirow{6}{*}{80} & 0 & $19.93 \pm 0.17$ & $60.24 \pm 0.33$ & $14.23 \pm 0.15$ & $5.60 \pm 0.05$ & $20.12 \pm 0.19$ & $60.18 \pm 0.30$ & $14.34 \pm 0.21$ & $5.36 \pm 0.09$ \\
\hline & 7 & $20.23 \pm 0.18$ & $60.18 \pm 0.32$ & $14.22 \pm 0.16$ & $5.37 \pm 0.05$ & $20.41 \pm 0.19$ & $60.15 \pm 0.31$ & $14.30 \pm 0.21$ & $5.14 \pm 0.11$ \\
\hline & 14 & $20.47 \pm 0.19$ & $60.14 \pm 0.31$ & $14.20 \pm 0.15$ & $5.19 \pm 0.06$ & $20.65 \pm 0.18$ & $60.10 \pm 0.31$ & $14.21 \pm 0.20$ & $5.04 \pm 0.09$ \\
\hline & 21 & $20.63 \pm 0.19$ & $61.16 \pm 0.32$ & $14.20 \pm 0.16$ & $5.07 \pm 0.06$ & $20.93 \pm 0.19$ & $60.07 \pm 0.32$ & $14.18 \pm 0.20$ & $4.82 \pm 0.10$ \\
\hline & 28 & $20.76 \pm 0.20$ & $60.07 \pm 0.29$ & $14.18 \pm 0.14$ & $4.98 \pm 0.05$ & $21.13 \pm 0.21$ & $60.03 \pm 0.31$ & $14.15 \pm 0.19$ & $4.69 \pm 0.12$ \\
\hline & 35 & $20.82 \pm 0.20$ & $60.06 \pm 0.30$ & $14.17 \pm 0.14$ & $4.95 \pm 0.05$ & $21.37 \pm 0.20$ & $60.00 \pm 0.31$ & $14.10 \pm 0.18$ & $4.53 \pm 0.11$ \\
\hline \multicolumn{2}{|c|}{ Fresh fish } & 76.40 & 17.40 & 4.68 & 1.52 & 76.40 & 17.40 & 4.68 & 1.52 \\
\hline \multicolumn{2}{|c|}{ L.S.D. } & 0.051 & 0.045 & 0.032 & 1.20 & 0.051 & 0.045 & 0.032 & 1.20 \\
\hline
\end{tabular}


concentration used. These results were agreed with Al-Temimi (2018) who found that the ash content in microwaved dried carp was decreased during the storage periods. Lithi et al. (2020) mentioned that the ash content in dried fish reached $9.60 \%$ and $10.16 \%$ using open sun drying and solar dryer respectively. The ash content in open sun dried fish was significantly higher because of deposition of dust and dirt particles on the fish (Rasul et al., 2018). The thiobarbituric acid (TBA) values for dried salted and unsalted Klunzinger's mullet by using different temperatures during different storage periods were shown in Figs.

(8) and (9).

\section{Chemical indices}

The $\mathrm{pH}$ values for dried salted and unsalted Klunzinger's mullet with different temperatures during different storage periods was shown in Figs. (7) and (8). The results showed that $\mathrm{pH}$ of dried salted fish was 5.90 , $5.95,6.01,6.11$ and 6.10 at temperatures of $60,65,70,75$ and $80{ }^{\circ} \mathrm{C}$ respectively at zero day of storage periods, and was $6.31,6.12$,
$6.35,6.41$ and 6.35 respectively after 35 days of storage. Furthermore, the $\mathrm{pH}$ values were $5.75,5.79,5.85,6.01$ and 6.08 at the same temperature respectively at zero day of storage periods. It was reached to $6.22,6.13$, $6.22,6.30$ and 6.30 respectively after 35 days of storage in dried unsalted fish. The results showed that $\mathrm{pH}$ of dried salted and unsalted Klunzinger's mullet increased with the storage periods and that the $\mathrm{pH}$ of salted fish was exceeded compared with unsalted fish. The reason for the increae of $\mathrm{pH}$ was the continuation of the protein decomposition process due to the continuation of the enzymatic activity, whether it was intrinsic or microbial which leads to the production and release of nitrogenous bases and amino acids, urea or ammonia, all of this led to an increase of $\mathrm{pH}$ (Elshehawy, etal., 2015). The results agreed with Fath El-Bab (2005) who found that the value of the $\mathrm{pH}$ was increased by using high salt concentration. The results were agreed with Patir et al. (2006) who found that the lowest and highest $\mathrm{pH}$ values of salted small mullet were 5.36 and 6.95 respectively.

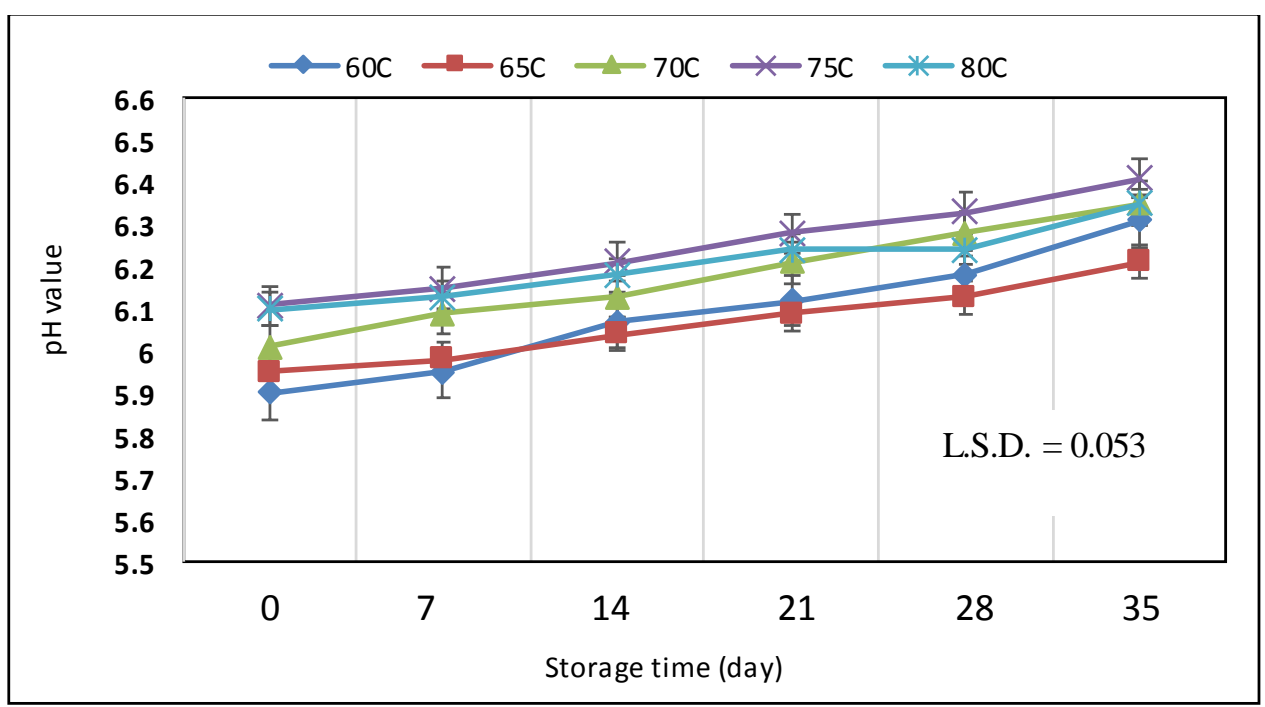

Fig. (7): pH value curve of Klunzinge r's mullet (salted) at a different temperature during different storage periods. 
Al- Rubaiy et al. / Basrah J. Agric. Sci., 33(1): 231- 260, 2020

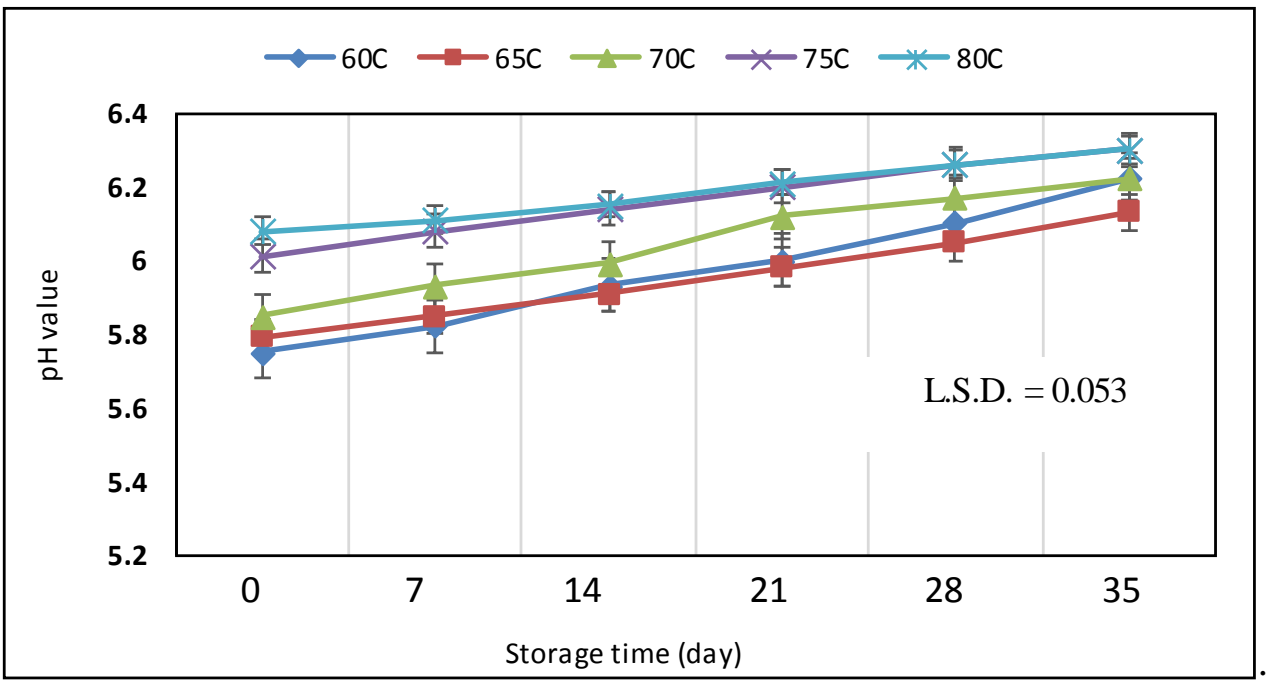

Fig. (8): pH value curve of Klunzinger's mullet (unsalted) at a diffe rent temperature during different storage periods.

\section{Mathe matical modeling of pH}

The mathematical modeling used to predict deterioration of product and calculation of reaction rate, as well as determination better model for fitting predicted and experimental data. The results in table (2) illustrated that the first order model can be used to predict $\mathrm{pH}$ value during storage periods compare with the Zero order model. This is because the statistical parameters such as root mean square error (RMSE) and chi square $\left(\mathrm{X}^{2}\right)$ for the first order model were less than the Zero order model at all drying temperatures in the salted and unsalted fish. As well as, the determination of coefficient $\left(\mathrm{R}^{2}\right)$ for the first order model was higher at all drying temperatures in the salted and unsalted fish. For example, when drying temperature was $60^{\circ} \mathrm{C}$ in salted fish, $\mathrm{k}_{0}$ and $\mathrm{k}_{1}$ were $-4.57 \times 10^{-4}$ $1 . \mathrm{h}^{-1}$ and $-7.55 \times 10^{-5} 1 . \mathrm{h}^{-1}$ respectively with RMSE, $\mathrm{X}^{2}$ and $\mathrm{R}^{2}$ reached 0.0189, 0.00357 and 0.9890 respectively for the zero order model, and reached to $0.01833,0.000392$ and 0.990335 respectively for the first order model. Rates constants were changed with temperature and process type (salted and unsalted). The relationship between rate constant and drying temperature was polynomial four orders in salted and unsalted fish as depicted in equations from (14) to (17):

$k_{0}$ (zeromodel,salted fish)

$$
\begin{aligned}
& =-4 \times 10^{-8} T^{4}+1 \\
& \times 10^{-5} T^{3}-0.0012 T^{2} \\
& +0.0585 T-1.0304 \\
& ; R^{2}=1
\end{aligned}
$$

$k_{1}$ (first model,salted fish)

$$
\begin{aligned}
& =-7 \times 10^{-9} T^{4}+2 \\
& \times 10^{-6} T^{3}-0.0002 T^{2} \\
& +0.0098 T-0.1728 \\
& R^{2}=1
\end{aligned}
$$

$$
\begin{aligned}
& k_{0(\text { zero model,unsalted } \text { ish })} \\
& \quad=-8 \times 10^{-8} T^{4}+2 \\
& \quad \times 10^{-5} T^{3}-0.0025 T^{2} \\
& +0.1155 T-2.0302 \\
& R^{2}=1
\end{aligned}
$$

$$
\begin{aligned}
& k_{1 \text { (first model,unsalted fish })} \\
& \quad=-1 \times 10^{-8} T^{4}+4 \\
& \quad \times 10^{-6} T^{3}-0.0004 T^{2} \\
& +0.0196 T-0.344 \\
& R^{2}=1
\end{aligned}
$$


Al- Rubaiy et al. / Basrah J. Agric. Sci., 33(1): 231- 260, 2020

Table (2). Results of mathe matical modeling and statistical parameters of $\mathrm{pH}$.

\begin{tabular}{|c|c|c|c|c|c|c|}
\hline $\begin{array}{l}\text { Process } \\
\text { type }\end{array}$ & $\begin{array}{c}\text { Drying } \\
\text { temperature } \\
\left({ }^{\circ} \mathrm{C}\right)\end{array}$ & Model order & $\begin{array}{c}\text { Rates } \\
\text { Constants }(1 / h)\end{array}$ & RMSE & $\mathrm{X}^{2}$ & $\mathrm{R}^{2}$ \\
\hline \multirow[t]{10}{*}{ salted } & \multirow[t]{2}{*}{60} & Zero order model & $\mathrm{k}_{0}=-4.57 \times 10^{-4}$ & 0.0189 & 0.00357 & 0.989000 \\
\hline & & First order model & $\mathrm{k}_{1}=-7.55 \times 10^{-5}$ & 0.01833 & 0.000392 & 0.990335 \\
\hline & \multirow[t]{2}{*}{65} & Zero order model & $\mathrm{k}_{0}=-2.87 \times 10^{-4}$ & 0.01145 & 0.002061 & 0.993076 \\
\hline & & First order model & $\mathrm{k}_{1}=-4.70 \times 10^{-5}$ & 0.00415 & 0.000834 & 0.993558 \\
\hline & \multirow[t]{2}{*}{70} & Zero order model & $\mathrm{k}_{0}=-4.00 \times 10^{-4}$ & 0.00747 & 0.001310 & 0.997534 \\
\hline & & First order model & $\mathrm{k}_{1}=-6.52 \times 10^{-5}$ & 0.00273 & 0.000516 & 0.997719 \\
\hline & \multirow[t]{2}{*}{75} & Zero order model & $\mathrm{k}_{0}=-3.39 \times 10^{-4}$ & 0.01051 & 0.001882 & 0.996232 \\
\hline & & First order model & $\mathrm{k}_{1}=-5.44 \times 10^{-5}$ & 0.00373 & 0.000735 & 0.996670 \\
\hline & \multirow[t]{2}{*}{80} & Zero order model & $\mathrm{k}_{0}=-2.62 \times 10^{-4}$ & 0.01897 & 0.003582 & 0.971224 \\
\hline & & First order model & $\mathrm{k}_{1}=-4.23 \times 10^{-5}$ & 0.00708 & 0.001590 & 0.971774 \\
\hline \multirow[t]{10}{*}{ unsalted } & \multirow[t]{2}{*}{60} & Zero order model & $\mathrm{k}_{0}=-5.34 \times 10^{-4}$ & 0.01359 & 0.002480 & 0.996797 \\
\hline & & First order model & $\mathrm{k}_{1}=-8.99 \times 10^{-5}$ & 0.00455 & 0.000920 & 0.997385 \\
\hline & \multirow[t]{2}{*}{65} & Zero order model & $\mathrm{k}_{0}=-2.28 \times 10^{-4}$ & 0.04200 & 0.009060 & 0.940442 \\
\hline & & First order model & $\mathrm{k}_{1}=-3.83 \times 10^{-5}$ & 0.01575 & 0.004652 & 0.941812 \\
\hline & \multirow[t]{2}{*}{70} & Zero order model & $\mathrm{k}_{0}=-4.65 \times 10^{-4}$ & 0.01697 & 0.003160 & 0.990578 \\
\hline & & First order model & $\mathrm{k}_{1}=-7.74 \times 10^{-5}$ & 0.00668 & 0.001470 & 0.989925 \\
\hline & \multirow[t]{2}{*}{75} & Zero order model & $\mathrm{k}_{0}=-3.63 \times 10^{-4}$ & 0.00805 & 0.001410 & 0.997392 \\
\hline & & First order model & $\mathrm{k}_{1}=-5.90 \times 10^{-5}$ & 0.00336 & 0.000650 & 0.9968 \\
\hline & \multirow[t]{2}{*}{80} & Zero order model & $\mathrm{k}_{0}=-2.58 \times 10^{-4}$ & 0.00854 & 0.001500 & 0.995706 \\
\hline & & First order model & $\mathrm{k}_{1}=-4.17 \times 10^{-5}$ & 0.00311 & 0.000590 & 0.995953 \\
\hline
\end{tabular}

RMSE is the root mean square error, $X^{2}$ is the chi square, $R^{2}$ is the determination coefficient, $k_{0}$ is the rate constant of the zeroorder model $1 . h^{-1}$ and $k_{1}$ is the rate constant of the first order model $1 . h^{-1}$.

The thiobarbituric acid (TBA) values for dried salted and unsalted Klunzinger's mullet by using different temperatures during different storage periods were shown in Figs. (9) and (10). The results showed that TBA values in fresh fish was $0.731 \mathrm{mg}$ malaldehyde. $\mathrm{kg}^{-1}$ and they were $0.939,0.961$, $0.966,1.011$ and $1.031 \mathrm{mg}$ malaldehyde. $\mathrm{kg}^{-1}$ for dried salted fish at temperatures of 60,65 ,
70,75 and $80^{\circ} \mathrm{C}$ respectively at zero day of storage periods, whereas they reached to $0.985,1.028,1.035,1.053$ and $1.057 \mathrm{mg}$ malaldehyde. $\mathrm{kg}^{-1}$ respectively after 35 days of storage. The results showed that TBA values were $1.221,1.226,1.221,1.211$ and $1.131 \mathrm{mg}$ malaldehyde. $\mathrm{kg}^{-1}$ at the same temperature respectively at zero day of storage periods, and after 35 days of storage were 1.254, 
Al- Rubaiy et al. / Basrah J. Agric. Sci., 33(1): 231- 260, 2020

$1.259, \quad 1.262, \quad 1.262$ and $1.167 \quad \mathrm{mg}$ malaldehyde. $\mathrm{kg}^{-1}$ respectively for dried unsalted fish. The results showed that TBA value for salted and unsalted dried fish was increased as the storage periods increased. This is due to the high percentage of fat after drying process. Also, it was due to the speed of drying process compared with conventional methods. Al-Shatty et al. (2014) indicated that TBA values was significantly affected by the drying method. The researchers noted that TBA values were higher when using solar drying than electric drying or using air drying. These results agreed with Al-Temimi (2018) who observed an increase in TBA values in microwaved dried carp fish with the increase of storage periods. The relationship between TBA and drying temperature and storage periods for salted and unsalted fish was given in the linear equations (18) and (19). In addition, the effect of drying temperature and storage periods on the TBA were significant $(\mathrm{P}<0.05)$.

$$
\begin{aligned}
& \text { TBA } A_{\text {salted }}=0.677+0.004 T+ \\
& 0.001 t ; \mathrm{R}=0.964 ; \mathrm{SE}=0.0129 \\
& \text { TBA } A_{\text {unsalted }}=0.962+0.003 T+ \\
& 0.001 t \quad ; \mathrm{R}=0.707 ; \mathrm{SE}=0.029
\end{aligned}
$$

Where, $T$ is the temperature $\left({ }^{\circ} \mathrm{C}\right), t$ is the storage period (day), $\mathrm{R}$ is the regression coefficient and SE is the standard error.

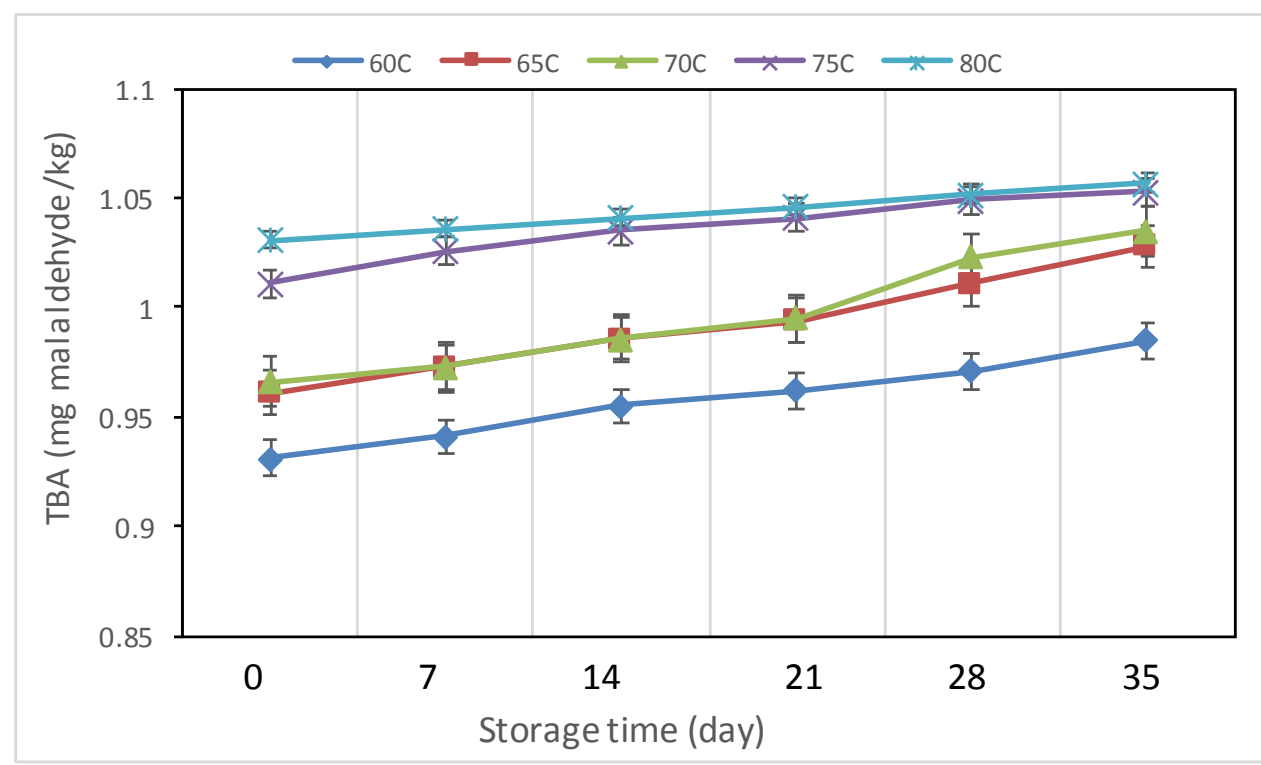

Fig. (9): TBA curve of Klunzinger's mullet (salted) at a different temperature during different storage periods. 
Al- Rubaiy et al. / Basrah J. Agric. Sci., 33(1): 231- 260, 2020

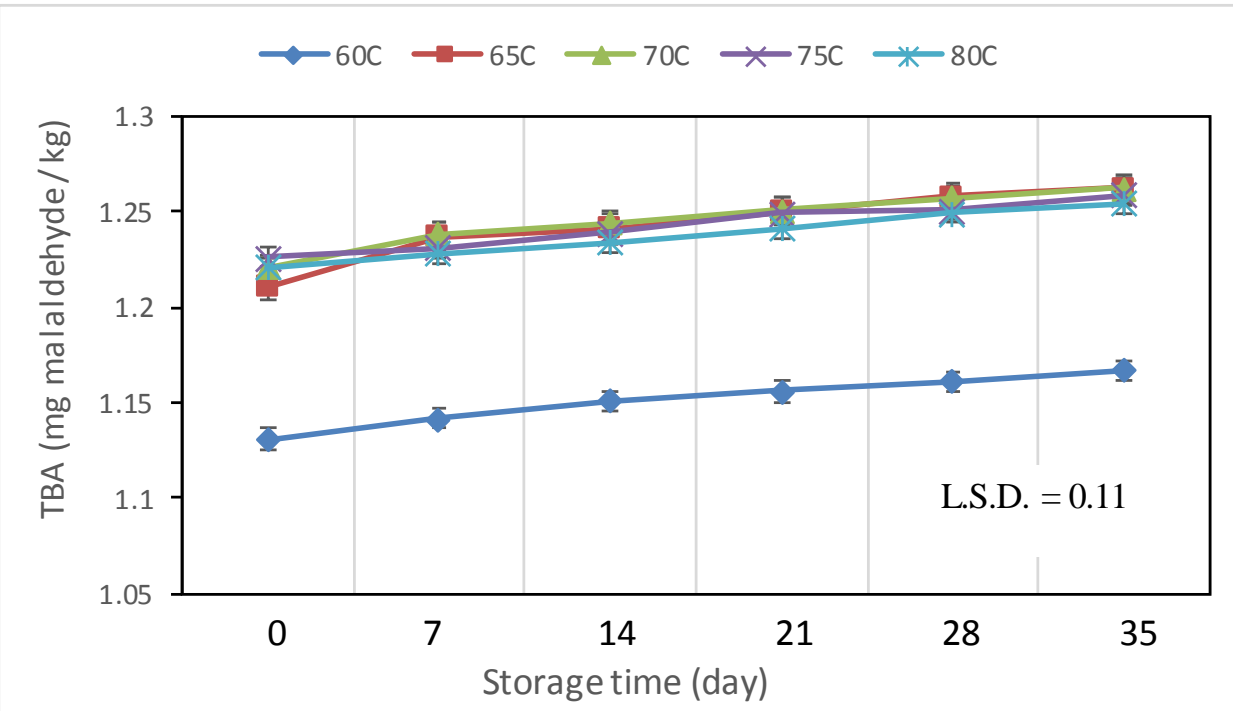

Fig. (10): TBA curve of Klunzinger's mullet at a different tempe rature during different storage

\section{Microbial tests}

Tables (3) and (4) clarified the microbial tests of dried salted and unsalted Klunzinger's mullet at different temperatures $(60,65,70,75$ and $\left.80^{\circ} \mathrm{C}\right)$ and storage periods $(0,7,14,21$, 28 and 35 days).Tables (3) and (4) showed that the total bacterial count was $9.00 \times 10^{3}$ cfu.g $\mathrm{g}^{-1}$ and $7.00 \times 10^{3}$ cfu.g $\mathrm{g}^{-1}$ in unsalted and salted fresh Klunzinger's mullet respectively. The results showed that the total bacterial count decreased after drying in unsalted fish to $3.50 \times 10^{3}, 3.46 \times 10^{3}, 3.00 \times 10^{3}, 2.90 \times 10^{3}$ and $2.10 \times 10^{3}$ cfu.g $^{-1}$ at temperatures of 60 , $65,70,75$ and $80^{\circ} \mathrm{C}$ at zero day of storage periods, and the total bacterial count were $4.12 \times 10^{3}, 4.12 \times 10^{3}, 3.80 \times 10^{3}, 3.10 \times 10^{3}$ and $2.89 \times 10^{3}$ cfu. $\mathrm{g}^{-1}$ respectively after 35 days of storage. In salted fish, the total bacterial count were $2.11 \times 10^{3}, 2.39 \times 10^{3}, 1.35 \times 10^{3}, 1.21 \times 10^{3}$ and $0.930 \times 10^{3} \quad$ cfu.g $^{-1}$ at the same temperature respectively at zero day of storage periods, and it reached $3.24 \times 10^{3}$, $2.12 \times 10^{3}, 1.96 \times 10^{3}, 1.76 \times 10^{3}$ and $1.011 \times 10^{3}$ cfu. $\mathrm{g}^{-1}$ respectively after 35 days of storage. The results disclosed that the total bacterial count was increasing in dried fish during storage because of storage temperature. The results were agreed with Al-Fadhly (2009) and Al-Temimi (2018) who noted that the total bacterial count increased in the microwaved dried carp fish with increasing storage periods. It can be seen from Tables (3) and (4) that the total coliform in salted fresh Klunzinger's mullet was $1.00 \times 10^{3}{\mathrm{cfu} . \mathrm{g}^{-1}}^{-1}$ and in unsalted fresh fish was $0.6 \times 10^{3} \mathrm{cfu}^{-} \mathrm{g}^{-}$ 1. The results showed that there was no growth of coliform in all studied samples of dried salted and unsalted Klunzinger's mullet. These results refer to improve the quality of the dried fish which be healthy and free from contaminated microbes. The results agreed with Al-Shatty et al. (2013) who found that the total coliform decreased significantly $(\mathrm{P}<0.05)$ in dried salted fish. The results were consistent with Al-Shatty at el. (2014) who showed that there was no growth of coliform in the dried carp fish and during the increase of the storage periods. Nur et al. (2020) found that the total viable count, total coliform count and fungal load were observed in dry fish up 3.50 x $105 \mathrm{CFU} / \mathrm{g}, 1.2 \mathrm{x} 103 \mathrm{CFU} / \mathrm{g}$ respectively.

Tables (3) and (4) illustrated that the total number of yeasts and molds in Klunzinger's mullet increased. The total number of yeasts in unsalted fresh fish was $2.50 \times 10^{2} \mathrm{cfu}^{-1}$. 
The results disclosed that the number of yeasts in dried unsalted fish decreased to $0.30 \times 10^{2}, 0.16 \times 10^{2}, 0.11 \times 10^{2}, 0.16 \times 10^{1}$ and $0.13 \times 10^{1}$ cfu.g $^{-1}$ using temperatures of 60,65 , 70,75 and $80{ }^{\circ} \mathrm{C}$ respectively at zero day of storage periods. The number of yeasts was $0.43 \times 10^{2}, 0.38 \times 10^{2}, 0.31 \times 10^{2}, 0.31 \times 10^{1}$ and $0.26 \times 10^{1}$ cfu.g-1 ${ }^{-1}$ espectively after 35 days of storage. In salted fresh fish, the total number of yeasts was $1.50 \times 10^{2} \mathrm{cfu}^{-1}$ and decreased to $0.25 \times 10^{2}, \quad 0.10 \times 10^{2}, \quad 0.10 \times 10^{2}, \quad 0.12 \times 10^{1}$ and $0.43 \times 10^{1}$ cfu.g ${ }^{-1}$ after drying at the same temperatures respectively at zero day of storage period. This number of yeasts was $0.40 \times 10^{2}, 0.31 \times 10^{2}, 0.22 \times 10^{2}, 0.26 \times 10^{1}$ and $0.17 \times 10^{1}$ cfu.g $^{-1}$ respectively after 35 days of storage. The results showed that the total number of molds in fresh unsalted fish was $4.00 \times 10^{3}$ cfu. $\mathrm{g}^{-1}$ and decreased after drying to $0.40 \times 10^{2}, \quad 0.36 \times 10^{2}, \quad 0.33 \times 10^{2}, \quad 0.24 \times 10^{1}$ and $0.21 \times 10$ cfu. $^{-1}$ at temperatures of 60,65 , 70, 75 and $80^{\circ} \mathrm{C}$ respectively at zero day of storage periods. It was $0.59 \times 10^{2}, 0.49 \times 10^{2}$, $0.44 \times 10^{2}, \quad 0.38 \times 10^{1}$ and $0.28 \times 10^{1}$ cfu.g $^{-1}$ respectively after 35 days of storage. In fresh salted fish, the total number of molds was $1.50 \times 10^{2}$ cfu. $\mathrm{g}^{-1}$ and decreased to $0.30 \times 10^{2}$, $0.20 \times 10^{2}, 0.29 \times 10^{2}, 0.20 \times 10^{1}$ and $0.18 \times 10^{1}$ cfu. $\mathrm{g}^{-1}$ after drying at the same temperatures respectively at zero day of storage periods. Number of molds increased to $0.53 \times 10^{2}, 0.46$ $\times 10^{2}, \quad 0.39 \times 10^{2}, 0.29 \times 10^{1}$ and $0.25 \times 10^{1}$ cfu. $\mathrm{g}^{-1}$ respectively after 35 days of storage. The reason for the increasing number of yeasts and molds in dried fish may be attributed to increase of storage temperature, packaging and storage. The results agreed with Al-Shatty at el. (2014) who observed an increase in the number of yeasts and molds in dried fish after drying process. Tables (3) and (4) disclosed the number of Staphylococcus aureus in unsalted and salted fresh Klunzinger's mullet were $0.893 \times 10^{3}$ and $0.716 \times 10^{3}$ cfu.g ${ }^{-1}$ respectively.

Table (3): Microbial Tests (cfu.g- ${ }^{-1}$ ) for Fresh and dried unsalted Klunzinger's mullet at different temperatures and during different storage periods.

\begin{tabular}{|c|c|c|c|c|c|c|}
\hline \multirow{2}{*}{$\begin{array}{c}\text { Drying } \\
\text { temperatu } \\
\text { re }\left({ }^{\circ} \mathrm{C}\right)\end{array}$} & \multirow{2}{*}{$\begin{array}{r}\text { Storage } \\
\text { periods }\end{array}$} & \multicolumn{5}{|c|}{ Microbiological content cfu.g $^{-1}$} \\
\hline & & $\begin{array}{c}\text { Total } \\
\text { bacteria }\end{array}$ & coliform & yeast & molds & $\begin{array}{l}\text { Staph. } \\
\text { aureus }\end{array}$ \\
\hline $\begin{array}{l}\text { unsalted } \\
\text { fresh fish }\end{array}$ & fresh & $9.00 \times 10^{3}$ & $1 \times 10^{3}$ & $2.50 \times 10^{2}$ & $4.00 \times 10^{3}$ & $0.893 \times 10^{3}$ \\
\hline \multirow{6}{*}{60} & 0 & $3.50 \times 10^{3}$ & 0 & $0.30 \times 10^{2}$ & $0.40 \times 10^{2}$ & $0.089 \times 10^{3}$ \\
\hline & 7 & $3.55 \times 10^{3}$ & 0 & $0.34 \times 10^{2}$ & $0.44 \times 10^{2}$ & $0.089 \times 10^{3}$ \\
\hline & 14 & $3.36 \times 10^{3}$ & 0 & $0.36 \times 10^{2}$ & $0.48 \times 10^{2}$ & $0.088 \times 10^{3}$ \\
\hline & 21 & $3.75 \times 10^{3}$ & 0 & $0.38 \times 10^{2}$ & $0.53 \times 10^{2}$ & $0.087 \times 10^{3}$ \\
\hline & 28 & $3.89 \times 10^{3}$ & 0 & $0.41 \times 10^{2}$ & $0.57 \times 10^{2}$ & $0.085 \times 10^{3}$ \\
\hline & 35 & $4.12 \times 10^{3}$ & 0 & $0.43 \times 10^{2}$ & $0.59 \times 10^{2}$ & $0.086 \times 10^{3}$ \\
\hline \multirow{6}{*}{65} & $\overline{0}$ & $3.46 \times 10^{3}$ & $\overline{0}$ & $0.16 \times 10^{2}$ & $0.36 \times 10^{2}$ & $0.066 \times 10^{3}$ \\
\hline & 7 & $3.66 \times 10^{3}$ & 0 & $0.19 \times 10^{2}$ & $0.38 \times 10^{2}$ & $0.065 \times 10^{3}$ \\
\hline & 14 & $3.87 \times 10^{3}$ & 0 & $0.22 \times 10^{2}$ & $0.41 \times 10^{2}$ & $0.065 \times 10^{3}$ \\
\hline & 21 & $3.93 \times 10^{3}$ & 0 & $0.32 \times 10^{2}$ & $0.43 \times 10^{2}$ & $0.066 \times 10^{3}$ \\
\hline & 28 & $4.10 \times 10^{3}$ & 0 & $0.37 \times 10^{2}$ & $0.46 \times 10^{2}$ & $0.067 \times 10^{3}$ \\
\hline & 35 & $4.12 \times 10^{3}$ & 0 & $0.38 \times 10^{2}$ & $0.49 \times 10^{2}$ & $0.068 \times 10^{3}$ \\
\hline
\end{tabular}


Al- Rubaiy et al. / Basrah J. Agric. Sci., 33(1): 231- 260, 2020

\begin{tabular}{|c|c|c|c|c|c|c|}
\hline \multirow{6}{*}{70} & 0 & $3.00 \times 10^{3}$ & $\overline{0}$ & $0.11 \times 10^{2}$ & $0.33 \times 10^{2}$ & $0.060 \times 10^{3}$ \\
\hline & 7 & $3.22 \times 10^{3}$ & $\overline{0}$ & $0.17 \times 10^{2}$ & $0.35 \times 10^{2}$ & $0.058 \times 10^{3}$ \\
\hline & 14 & $3.41 \times 10^{3}$ & 0 & $0.20 \times 10^{2}$ & $0.38 \times 10^{2}$ & $0.057 \times 10^{3}$ \\
\hline & 21 & $3.53 \times 10^{3}$ & 0 & $0.23 \times 10^{2}$ & $0.41 \times 10^{2}$ & $0.057 \times 10^{3}$ \\
\hline & 28 & $3.64 \times 10^{3}$ & 0 & $0.27 \times 10^{2}$ & $0.43 \times 10^{2}$ & $0.058 \times 10^{3}$ \\
\hline & 35 & $3.80 \times 10^{3}$ & $\overline{0}$ & $0.31 \times 10^{2}$ & $0.44 \times 10^{2}$ & $0.058 \times 10^{3}$ \\
\hline \multirow{6}{*}{75} & 0 & $2.90 \times 10^{3}$ & $\overline{0}$ & $0.16 \times 10^{1}$ & $0.24 \times 10^{1}$ & $0.446 \times 10^{2}$ \\
\hline & 7 & $2.92 \times 10^{3}$ & $\overline{0}$ & $0.19 \times 10^{1}$ & $0.29 \times 10^{1}$ & $0.446 \times 10^{2}$ \\
\hline & 14 & $2.94 \times 10^{3}$ & 0 & $0.21 \times 10^{1}$ & $0.31 \times 10^{1}$ & $0.442 \times 10^{2}$ \\
\hline & 21 & $2.96 \times 10^{3}$ & 0 & $0.24 \times 10^{1}$ & $0.32 \times 10^{1}$ & $0.444 \times 10^{2}$ \\
\hline & 28 & $3.01 \times 10^{3}$ & 0 & $0.27 \times 10^{1}$ & $0.36 \times 10^{1}$ & $0.445 \times 10^{2}$ \\
\hline & 35 & $3.10 \times 10^{3}$ & 0 & $0.31 \times 10^{1}$ & $0.38 \times 10^{1}$ & $0.446 \times 10^{2}$ \\
\hline \multirow{6}{*}{80} & 0 & $2.10 \times 10^{3}$ & 0 & $0.13 \times 10^{1}$ & $0.21 \times 10^{1}$ & $0.329 \times 10^{2}$ \\
\hline & 7 & $2.21 \times 10^{3}$ & 0 & $0.16 \times 10^{1}$ & $0.22 \times 10^{1}$ & $0.326 \times 10^{2}$ \\
\hline & 14 & $2.33 \times 10^{3}$ & $\overline{0}$ & $0.17 \times 10^{1}$ & $0.25 \times 10^{1}$ & $0.323 \times 10^{2}$ \\
\hline & 21 & $2.55 \times 10^{3}$ & 0 & $0.21 \times 10^{1}$ & $0.25 \times 10^{1}$ & $0.327 \times 10^{2}$ \\
\hline & 28 & $2.81 \times 10^{3}$ & 0 & $0.22 \times 10^{1}$ & $0.27 \times 10^{1}$ & $0.328 \times 10^{2}$ \\
\hline & 35 & $2.89 \times 10^{3}$ & 0 & $0.26 \times 10^{1}$ & $0.28 \times 10^{1}$ & $0.328 \times 10^{2}$ \\
\hline \multicolumn{2}{|c|}{ L.S.D. } & $0.340 \times 10^{3}$ & - & $0.05 \times 10^{2}$ & $0.05 \times 10^{2}$ & $0.03 \times 10^{2}$ \\
\hline
\end{tabular}

Table (4): Microbial Tests (cfu.g ${ }^{-1}$ ) for Fresh and dried salted Klunzinger's mullet at different temperatures and during different storage periods.

\begin{tabular}{|c|c|c|c|c|c|c|}
\hline $\begin{array}{c}\text { Drying } \\
\text { temperature } \\
\left({ }^{\mathbf{o}} \mathbf{C}\right)\end{array}$ & \multirow{2}{*}{$\begin{array}{c}\text { Storagep } \\
\text { eriods }\end{array}$} & $\begin{array}{c}\text { Total } \\
\text { bacteria }\end{array}$ & coliform & yeast & molds & $\begin{array}{c}\text { Staph. } \\
\text { aureus }\end{array}$ \\
\hline $\begin{array}{c}\text { salted fresh } \\
\text { fish }\end{array}$ & fresh & $7.00 \times 10^{3}$ & $0.6 \times 10^{3}$ & $1.00 \times 10^{2}$ & $1.50 \times 10^{2}$ & $0.716 \times 10^{3}$ \\
\hline \multirow{4}{*}{60} & 0 & $2.11 \times 10^{3}$ & 0 & $0.25 \times 10^{2}$ & $0.30 \times 10^{2}$ & $0.070 \times 10^{3}$ \\
\cline { 2 - 7 } & 7 & $2.31 \times 10^{3}$ & 0 & $0.29 \times 10^{2}$ & $0.35 \times 10^{2}$ & $0.069 \times 10^{3}$ \\
\cline { 2 - 7 } & 14 & $2.57 \times 10^{3}$ & 0 & $0.31 \times 10^{2}$ & $0.39 \times 10^{2}$ & $0.069 \times 10^{3}$ \\
\cline { 2 - 7 } & 21 & $2.89 \times 10^{3}$ & 0 & $0.35 \times 10^{2}$ & $0.43 \times 10^{2}$ & $0.068 \times 10^{3}$ \\
\cline { 2 - 7 } & 28 & $3.10 \times 10^{3}$ & 0 & $0.38 \times 10^{2}$ & $0.50 \times 10^{2}$ & $0.068 \times 10^{3}$ \\
\hline \multirow{4}{*}{65} & 35 & $3.24 \times 10^{3}$ & 0 & $0.40 \times 10^{2}$ & $0.53 \times 10^{2}$ & $0.068 \times 10^{3}$ \\
\cline { 2 - 7 } & 0 & $2.39 \times 10^{3}$ & 0 & $0.10 \times 10^{2}$ & $0.20 \times 10^{2}$ & $0.063 \times 10^{3}$ \\
\cline { 2 - 7 } & 14 & $2.52 \times 10^{3}$ & 0 & $0.14 \times 10^{2}$ & $0.26 \times 10^{2}$ & $0.062 \times 10^{3}$ \\
\cline { 2 - 7 } & 21 & $1.57 \times 10^{3}$ & 0 & $0.16 \times 10^{2}$ & $0.29 \times 10^{2}$ & $0.062 \times 10^{3}$ \\
\cline { 2 - 7 } & 28 & $2.02 \times 10^{3}$ & 0 & $0.20 \times 10^{2}$ & $0.32 \times 10^{2}$ & $0.061 \times 10^{3}$ \\
\cline { 2 - 7 } & 35 & $2.12 \times 10^{3}$ & 0 & $0.31 \times 10^{2}$ & $0.46 \times 10^{2}$ & $0.060 \times 10^{3}$ \\
\hline & 0 & $1.35 \times 10^{3}$ & 0 & $0.10 \times 10^{2}$ & $0.29 \times 10^{2}$ & $0.051 \times 10^{3}$ \\
\cline { 2 - 7 } & 7 & $1.41 \times 10^{3}$ & 0 & $0.11 \times 10^{2}$ & $0.31 \times 10^{2}$ & $0.051 \times 10^{3}$ \\
\cline { 2 - 7 } & 14 & $1.55 \times 10^{3}$ & 0 & $0.14 \times 10^{2}$ & $0.34 \times 10^{2}$ & $0.051 \times 10^{3}$ \\
\cline { 2 - 7 } & 21 & $1.72 \times 10^{3}$ & 0 & $0.17 \times 10^{2}$ & $0.37 \times 10^{2}$ & $0.052 \times 10^{3}$ \\
\hline
\end{tabular}


Al- Rubaiy et al. / Basrah J. Agric. Sci., 33(1): 231- 260, 2020

\begin{tabular}{|c|c|c|c|c|c|c|}
\hline & 28 & $1.84 \times 10^{3}$ & 0 & $0.20 \times 10^{2}$ & $0.37 \times 10^{2}$ & $0.053 \times 10^{3}$ \\
\hline & 35 & $1.96 \times 10^{3}$ & 0 & $0.22 \times 10^{2}$ & $0.39 \times 10^{2}$ & $0.053 \times 10^{3}$ \\
\hline \multirow{6}{*}{75} & 0 & $1.21 \times 10^{3}$ & 0 & $0.12 \times 10^{2}$ & $0.20 \times 10^{1}$ & $0.426 \times 10^{2}$ \\
\hline & 7 & $2.28 \times 10^{3}$ & 0 & $0.15 \times 10^{2}$ & $0.23 \times 10^{1}$ & $0.426 \times 10^{2}$ \\
\hline & 14 & $1.39 \times 10^{3}$ & 0 & $0.18 \times 10^{2}$ & $0.25 \times 10^{1}$ & $0.428 \times 10^{2}$ \\
\hline & 21 & $1.41 \times 10^{3}$ & 0 & $0.19 \times 10^{2}$ & $0.27 \times 10^{1}$ & $0.432 \times 10^{2}$ \\
\hline & 28 & $1.62 \times 10^{3}$ & 0 & $0.22 \times 10^{2}$ & $0.27 \times 10^{1}$ & $0.435 \times 10^{2}$ \\
\hline & 35 & $1.76 \times 10^{3}$ & 0 & $0.26 \times 10^{2}$ & $0.29 \times 10^{1}$ & $0.437 \times 10^{2}$ \\
\hline \multirow{6}{*}{80} & 0 & $0.930 \times 10^{3}$ & 0 & $0.10 \times 10^{1}$ & $0.18 \times 10^{1}$ & $0.316 \times 10^{2}$ \\
\hline & 7 & $0.994 \times 10^{3}$ & 0 & $0.12 \times 10^{1}$ & $0.21 \times 10^{1}$ & $0.312 \times 10^{2}$ \\
\hline & 14 & $0.996 \times 10^{3}$ & 0 & $0.14 \times 10^{1}$ & $0.22 \times 10^{1}$ & $0.309 \times 10^{2}$ \\
\hline & 21 & $1.006 \times 10^{3}$ & 0 & $0.15 \times 10^{1}$ & $0.22 \times 10^{1}$ & $0.311 \times 10^{2}$ \\
\hline & 28 & $1.008 \times 10^{3}$ & 0 & $0.15 \times 10^{1}$ & $0.24 \times 10^{1}$ & $0.312 \times 10^{2}$ \\
\hline & 35 & $0.011 \times 10^{3}$ & 0 & $0.17 \times 10^{1}$ & $0.25 \times 10^{1}$ & $0.312 \times 10^{2}$ \\
\hline \multicolumn{2}{|c|}{ L.S.D. } & $0.340 \times 10^{3}$ & - & $0.05 \times 10^{2}$ & $0.05 \times 10^{2}$ & $0.03 \times 10^{2}$ \\
\hline
\end{tabular}

The results showed that this number decreased in dried unsalted fish to $0.089 \times 10^{3}$, $0.066 \times 10^{3}, 0.060 \times 10^{3}, 0.446 \times 10^{2}$ and 0.329 $\times 10^{2}$ cfu.g $^{-1}$ at temperatures of $60,65,70,75$ and $80{ }^{\circ} \mathrm{C}$ respectively at zero day of storage periods. It was $0.086 \times 10^{3}, 0.068 \times 10^{3}, 0.058$ $\times 10^{3}, \quad 0.446 \times 10^{2}$ and $0.328 \times 10^{2}$ cfu. $^{-1}$ respectively after 35 days of storage, whereas in dried salted fish, the number of Staphylococcus aureus was $0.716 \times 10^{3}$.

The results showed that this number decreased in dried salted fish to $0.070 \times 10^{3}$, $0.063 \times 10^{3}, 0.051 \times 10^{3}, 0.426 \times 10^{2}$ and 0.316 $\times 10^{2}$ cfu.g $^{-1}$ at the same temperature respectively at zero day of storage periods. This number reached $0.068 \times 10^{3}, 0.060 \times 10^{3}$, $0.053 \times 10^{3}, 0.437 \times 10^{2}$ and $0.312 \times 10^{2} \mathrm{cfu}^{-1}$ respectively after 35 days of storage.

The results clarified that decreased numbers of Staphylococcus aureus in dried salted fish compared with dried unsalted fish may be due to the method of salting that made integrated hygienic conditions, which led to a reduce risk of Staphylococcus aureus, which causes staphylococcal poisoning. These results agreed with Fath El-Bab (2005) who showed that bacterial load decreases during drying and storing Sardine fish, and the results agreed with Al-Fadhli (2009) who observed an increase in the number of Staphylococcus aureus in dried Thelah fish (Scomberoides commersonnianus) using a solar dryer.

The results showed that Salmonella was not present in all samples of Klunzinger's mullet, whether fresh or dried, because of the drying process eliminated all microbes. All standard specifications indicated that Salmonella are not allowed in food (Stannard, 1997). The results agreed with Al-Shatty at el. (2013) who proved that Salmonella did not growth in dried salted fish .The results were consistent with Al-Shatty et al. (2014) who showed that there was no growth of Salmonella in dried carp fish and during increase of storage periods. Deng et al. (2020) stated that the average counts of bacteria, yeasts and filamentous fungi in the dried fish were 3.2, 2.5 and $2.2 \log \mathrm{cfu} \mathrm{g}^{-1}$, and increased to 4.6, 3.6 and $3.9 \log$ cfu $^{-1}$, respectively after 50 days of storage.

\section{Rehydration}


Figs. (11) and (12) showed the changes in the rehydration of dried salted and unsalted Klunzinger's mullet at different temperatures $\left(60,65,70,75\right.$ and $\left.80^{\circ} \mathrm{C}\right)$ and storage periods. The results showed that the rehydration of dried salted Klunzinger's mullet was 1.84, 1.87, 1.86, 1.84 and $1.81 \%$ at temperatures of $60,65,70,75$ and $80{ }^{\circ} \mathrm{C}$ respectively at zero day of storage periods. After that the rehydration decreased with the increase of the storage periods until it reached to $1.60,1.58,1.68,1.54$ and $1.58 \%$ respectively after 35 days of storage. The results illustrated that the rehydration of dried unsalted Biayah fish was 1.86, 1.76, 1.81, 1.79 and $1.74 \%$ at the same temperature respectively at the zero day of storage periods. It was $1.61,1.55,1.64,1.63$ and 1.56 $\%$ respectively after 35 days of storage. This is due to the absorption of moisture from the atmosphere and it effected on the chemical composition. The results showed that the rehydration decreased with increasing temperatures and that may be due to increase of surface hardening of the fish at high temperature and because of the protein denaturation due to high temperature and weakened its capacity for water carrying. Krokida \& Morinos- Kouris (2003) indicated that rehydration was influenced by a combination of factors such as cellular regulation, porosity of composition and mechanical properties for the dried material, as well as the drying method. Al-Shatty, et al. (2014) found that the rehydration of dried salted carp fish by oven was $1.34 \%$ and decreased to1.30 \% using natural sun drying. The results agreed with Al-Temimi (2018) who found that the rehydration in microwaved dried carp fish was decreased with the increase of energy levels from 100 to 500 watts and reached to 1.73 to $1.49 \%$ respectively. Kiin-Kabari \& Obasi (2020) indicated that the rehydration ratio of whelk was 1.47. Achaglinkame et al. (2020) clarified that freeze-dried samples of fish had higher percent rehydration where ranged between to102\%.

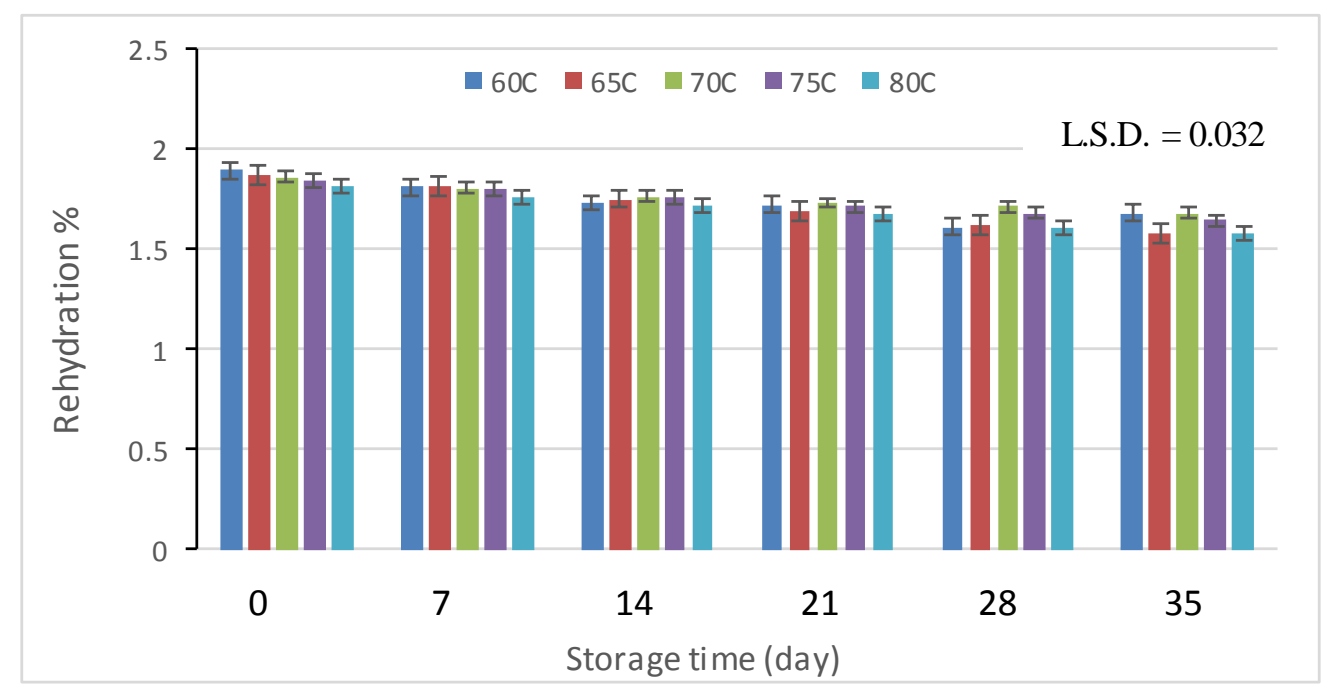

Fig. (11): Rehydration of Klunzinger's mullet (salted) at a diffe rent te mperature during different storage periods. 
Al- Rubaiy et al. / Basrah J. Agric. Sci., 33(1): 231- 260, 2020

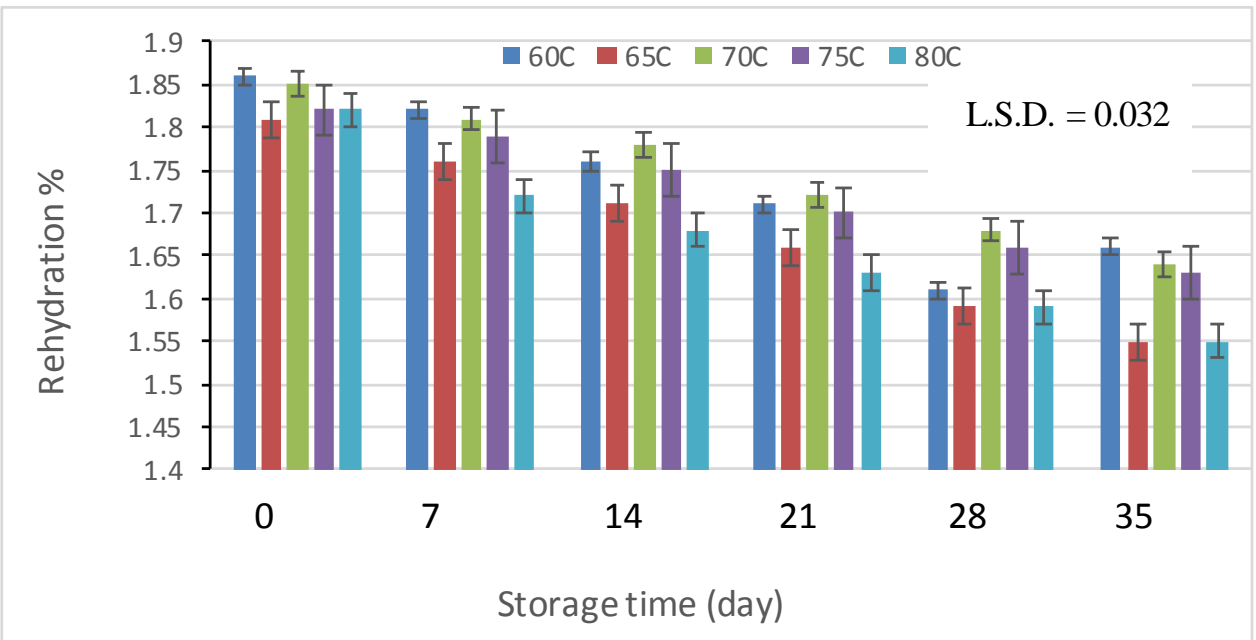

Fig. (12): Rehydration of Klunzinger's mullet (unsalted) at a different temperature during different storage periods.

\section{Artificial Neural Network (ANN) for modeling of moisture content}

ANN was used to predict moisture content of salted fish because their qualitative characteristics better than unsalted. Fig. (13) illustrated results of ANN for predicting moisture content of salted fish vs. drying time at different drying temperatures. The results showed that the predicted moisture content by ANN has a good fitting for experimental data at all drying temperatures. The relationship between predicted and experimental moisture content was strong with $\mathrm{R}^{2}=0.986$ as illustrated in fig. (14). The errors of model were depicted in table (5) where the sum of squares error for training and testing were 0.33 and 0.045 respectively, as well as the relative errors of training and testing were very small. The residual vs. predicted moisture content by ANN was depicted in fig. (15). The important factor that effect on the moisture content was drying time (0.929) with normalize importance of $100 \%$, but the importance of drying temperature was reduced and reached 0.071 with normalize importance of $7.6 \%$ (Fig. 16). It can be seen from the results that the ANN can be used to predict moisture content of fish. Boeri et al.
(2011) stated that simulations with the ANN model had a good results of moisture content of salted codfish, in addition neural network model is a promising potential. Equations from 20-24 describe the predicted moisture contents at drying temperatures from 60-80 ${ }^{\circ} \mathrm{C}$. Fig. 17. Illustrates photos of fresh and treatment of salted dried fish (at $80^{\circ} \mathrm{C}$ ) compared with unsalted.

$$
\begin{aligned}
& \mathrm{MC}_{60}{ }^{\circ} \mathrm{C}=4 \mathrm{E}-09 \mathrm{x}^{4}-3 \mathrm{E}-06 \mathrm{x}^{3}+0.0006 \mathrm{x}^{2}- \\
& 0.0622 \mathrm{x}+3.01 ; \mathrm{R}^{2}=0.9999 \\
& \mathrm{MC}_{65^{\circ} \mathrm{C}}=-1 \mathrm{E}-11 \mathrm{x}^{5}+1 \mathrm{E}-08 \mathrm{x}^{4}-4 \mathrm{E}-06 \mathrm{x}^{3}+ \\
& 0.0007 \mathrm{x}^{2}-0.0651 \mathrm{x}+3.2622 ; \mathrm{R}^{2}= \\
& 0.9999
\end{aligned}
$$

$$
\begin{aligned}
& \mathrm{MC}_{70^{\circ} \mathrm{C}}=5 \mathrm{E}-09 \mathrm{x}^{4}-3 \mathrm{E}-06 \mathrm{x}^{3}+0.0006 \mathrm{x}^{2}- \\
& 0.0621 \mathrm{x}+3.3981 ; \mathrm{R}^{2}=0.9998 \\
& \mathrm{MC}_{75^{\circ} \mathrm{C}}=-7 \mathrm{E}-12 \mathrm{x}^{5}+1 \mathrm{E}-08 \mathrm{x}^{4}-4 \mathrm{E}-06 \mathrm{x}^{3}+ \\
& 0.0007 \mathrm{x}^{2}-0.0651 \mathrm{x}+3.4178 ; \mathrm{R}^{2}= \\
& 0.9999
\end{aligned}
$$

$\mathrm{MC}_{80}{ }^{\circ} \mathrm{C}=7 \mathrm{E}-09 \mathrm{x}^{4}-4 \mathrm{E}-06 \mathrm{x}^{3}+0.0007 \mathrm{x}^{2}-$

$0.0653 \mathrm{x}+3.3022 ; \mathrm{R}^{2}=0.9999$

Where, $\mathrm{MC}$ is the moisture content (g water/g d.b.) and $\mathrm{x}$ is the drying time (min.) 
Al- Rubaiy et al. / Basrah J. Agric. Sci., 33(1): 231- 260, 2020

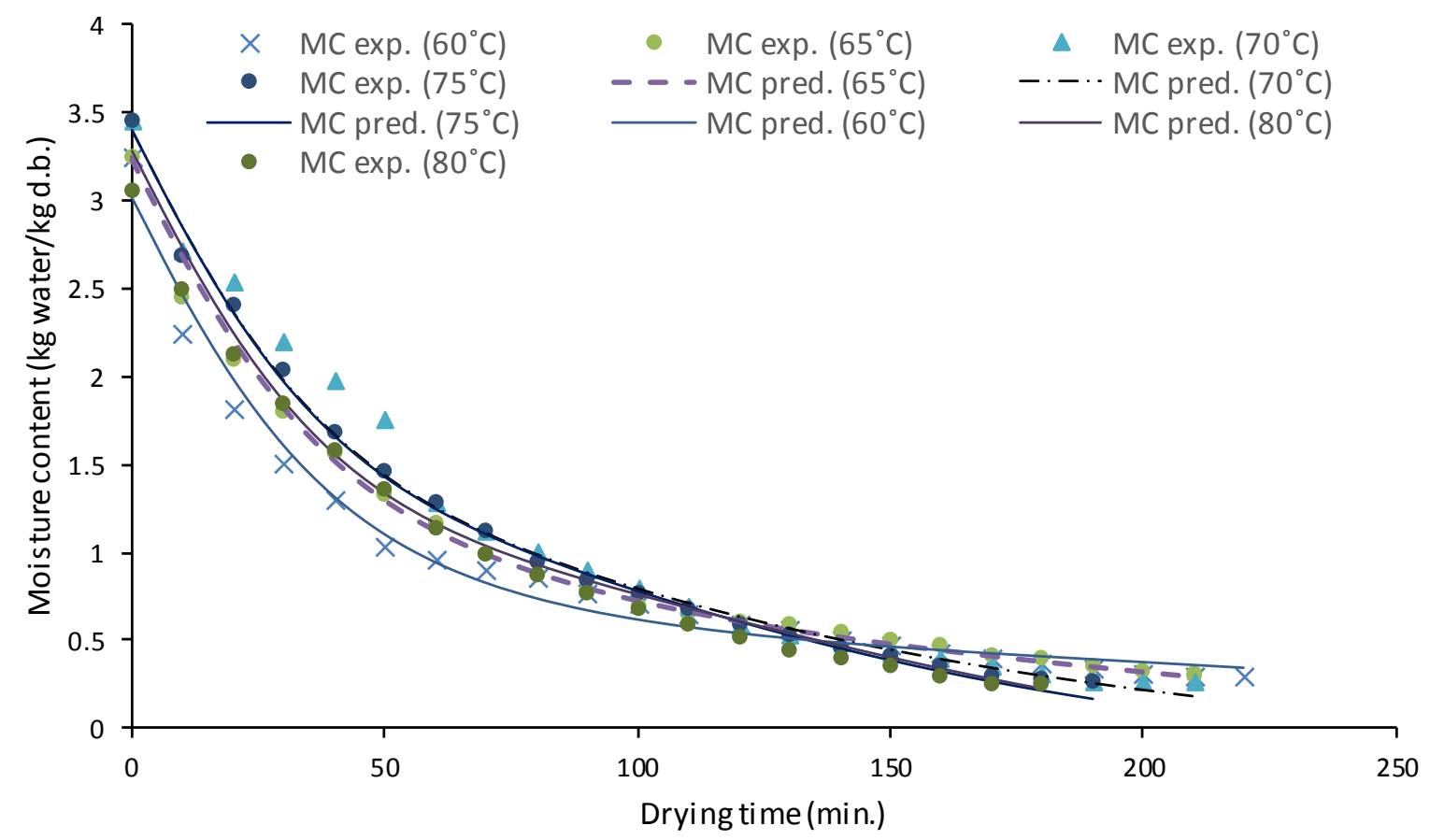

Fig. (13): Results of ANN for predicting moisture content of fish at different drying tempe ratures. MC exp.: experimental Mois ture content, MC pre.: predicted mois ture content.

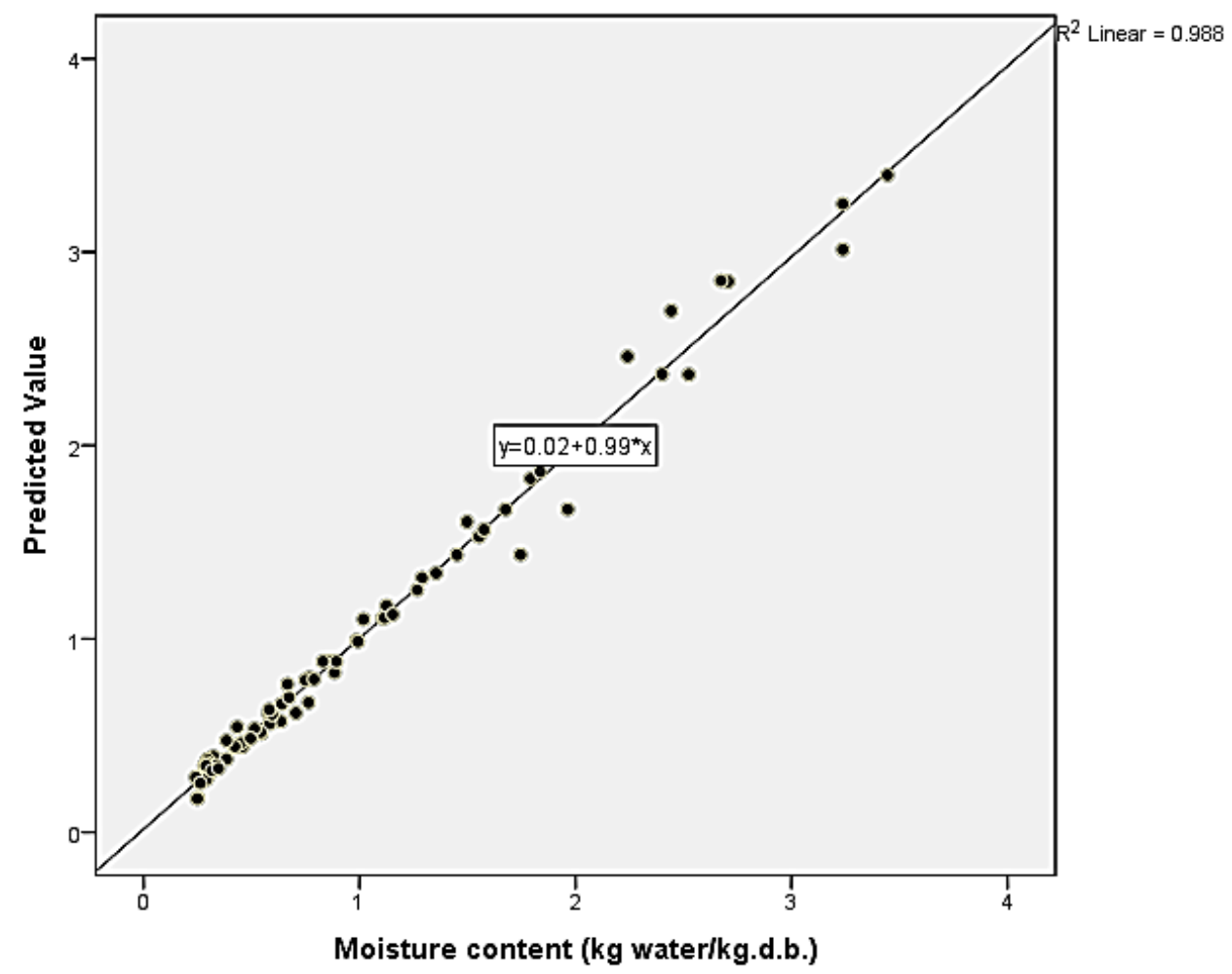

Fig. (14): Results of ANN for predicting moisture content of fish vs. moisture content (experimental). 
Al- Rubaiy et al. / Basrah J. Agric. Sci., 33(1): 231- 260, 2020

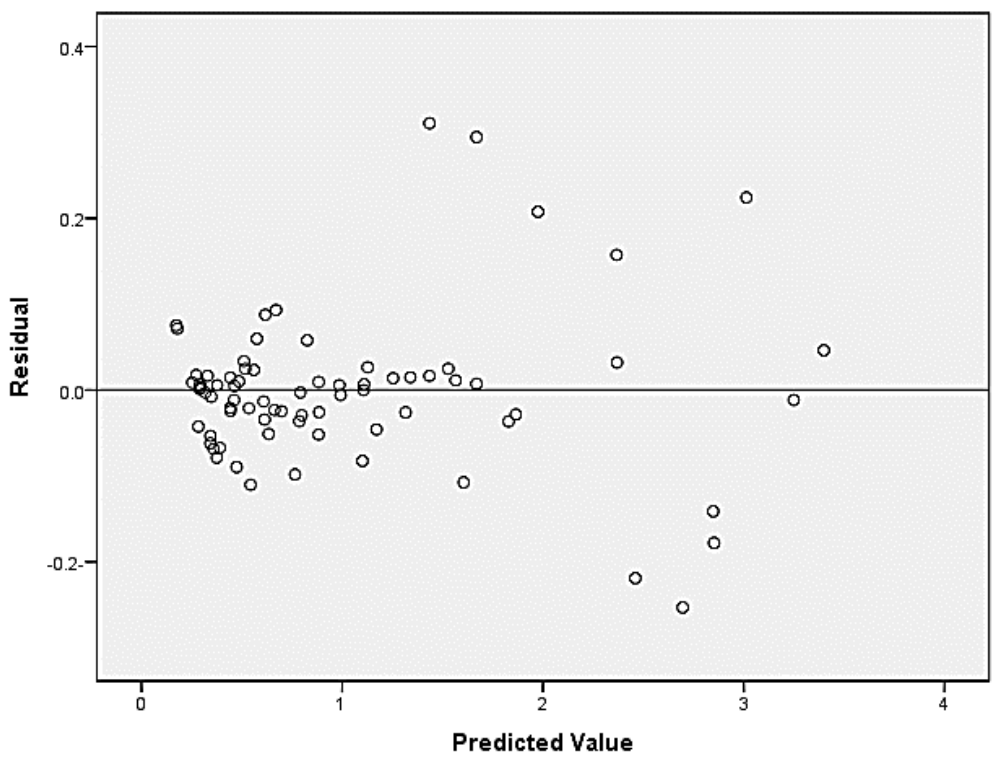

Dependent Variable: Moisture content

Fig. (15): The residual vs. predicted moisture content by ANN.

Table (5): Model Summary which predicted by ANN.

\begin{tabular}{|l|l|c|}
\hline \multirow{2}{*}{ Training } & Sum of Squares Error & .333 \\
\cline { 2 - 3 } & Relative Error & .012 \\
\hline \multirow{2}{*}{ Testing } & Sum of Squares Error & .048 \\
\cline { 2 - 3 } & Relative Error & .019 \\
\hline Holdout & Relative Error & .012 \\
\hline Dependent Variable: Moisture content \\
Error computations are based on the testing sample.
\end{tabular}

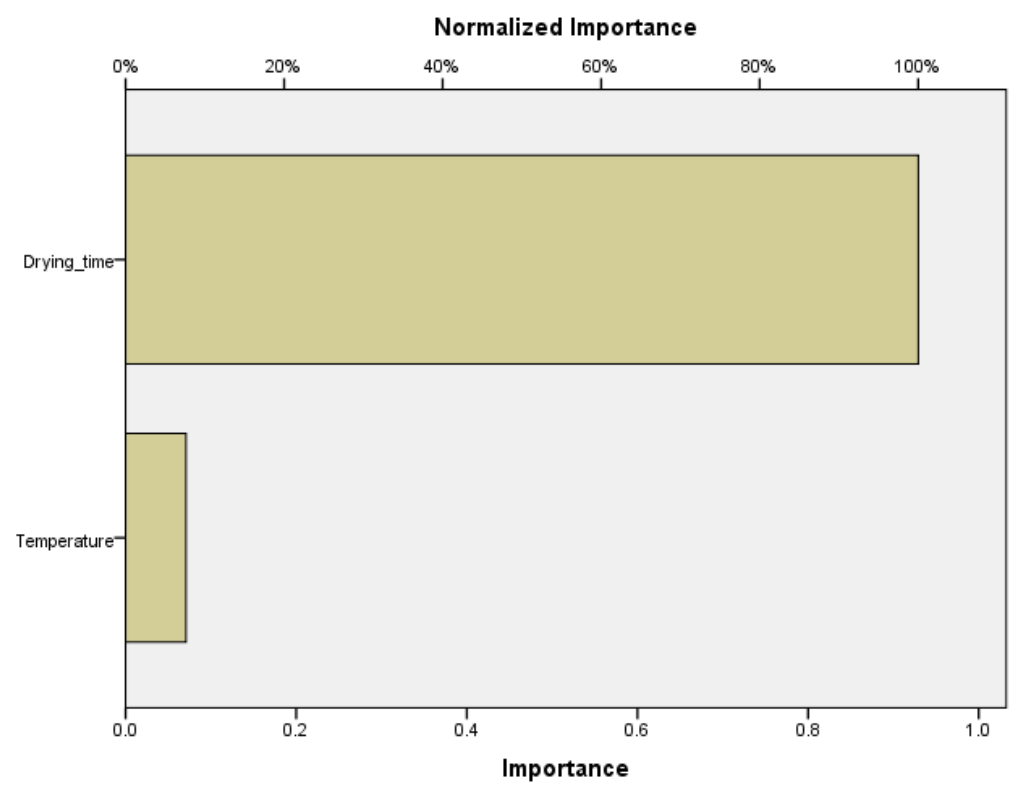

Fig. (16): Independent variables importance. 


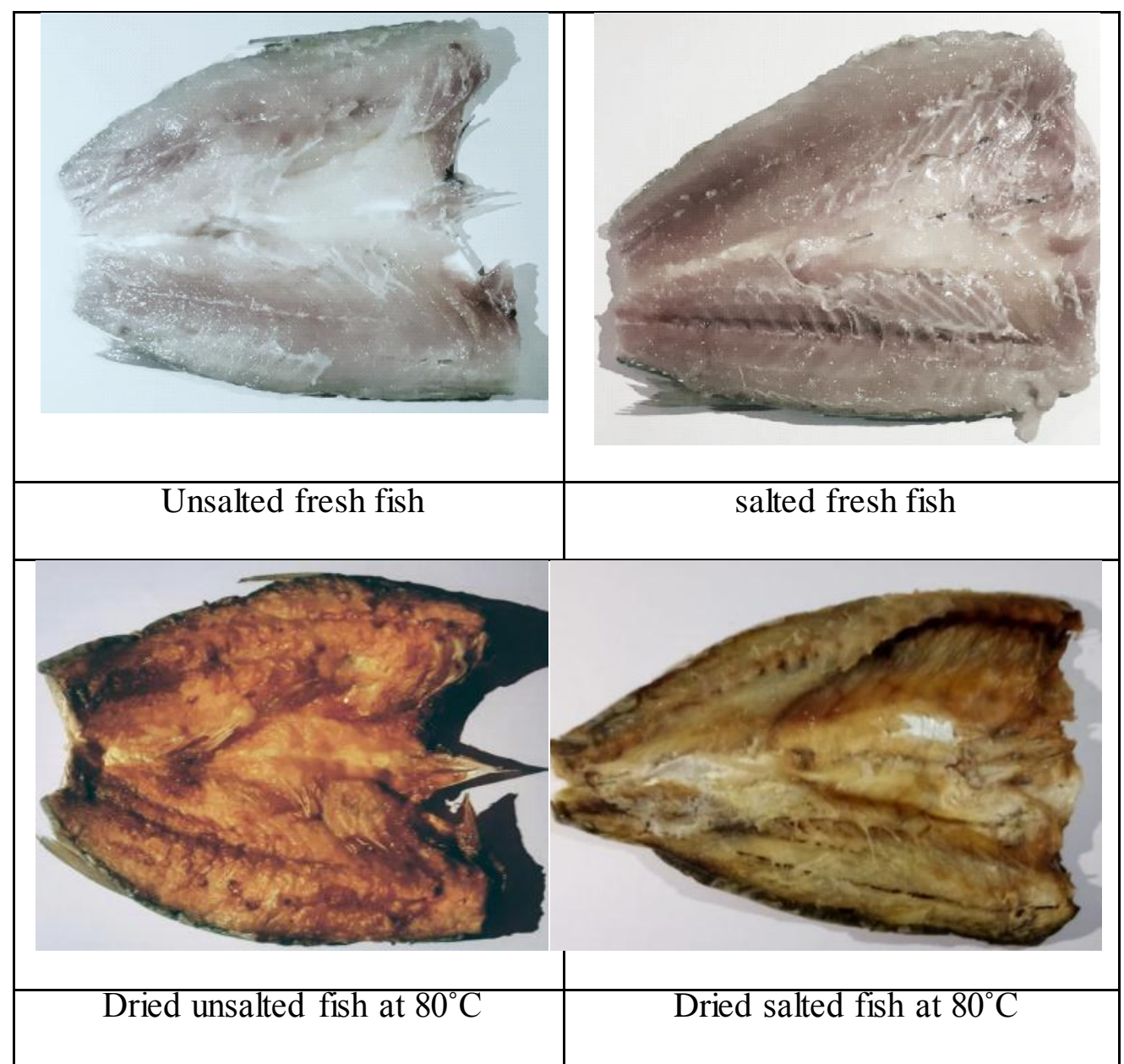

Fig. (17): Photos of fresh and best treatment of salted dried fish $\left(\right.$ at $\left.80^{\circ} \mathrm{C}\right)$ compared with unsalted. efficiency and produce product with high quality.

\section{Conclusions}

The study showed that the use of halogen

\section{The current challenges of halogen drye $r$}

The current challenges of halogen dryer were the evaporated water which exist from fish is condensate in the inner wall of dryer and fall into the container of fish which reduces drying efficiency.

\section{Future prospects}

To develop the halogen dryer, a concave ban made of Pyrex put under drying container to prevent re evaporation of condensate water. Moreover, the halogen dryer should be continuous. In addition, A vacuum system with halogen energy can be used to improve drying kinetics and increasing drying dryer in the drying process gave a high efficiency and a short time. The results showed that drying efficiency decreased as

temperature increased. The results showed that salted fish were faster than unsalted fish in the drying process. The results revealed that the chemical composition, qualitative characteristics and microbiological content of dried salted and unsalted Klunzinger's mullet have been changed during storage periods. The results showed that the rate of rehydration at higher temperatures for dried salted and unsalted Klunzinger's mullet 
decreased. ANN was gave a good fitting for moisture content.

\section{Acknowledgements}

We would like to thank Department of Food Science, College of Agriculture, University of Basrah for providing the laboratory and facilities to complete the research.

\section{Conflicts of interest}

The authors declare that they have no conflict of interests.

\section{Ethical approval}

All applicable institutional, national and international guidelines for the care and use of animals were followed.

\section{References}

Aboud, S.A.; Al-Temimi, A.B.; Al-Hilphy, A.R.S.; Yi-Chen, L. \& Cacciola, F. (2019). A comprehensive review on infrared heating applications in food processing. Molecules, $\quad 24(22)$ : $\quad 4125$. https://doi.org/10.3390/molecules2422412 5

Achaglinkame, M.A.; Owusu-Mensah, E.; Boakye, A.A. \& Oduro, I. (2020). Effect of effect of size and drying time on the rehydration and sensory properties of freeze-dried snails (Achatina achatina). Int. J. Food Sci., 2020: 1-5. https://doi.org/10.1155/2020/5714140

Al-Bayati, M.M.A. \& Ahmed, B.A. (2008). Albumin preparation and study of mullet fish chemical composition and functional properties. Diyala J. Food Tech. Humanity, 32: 242-254. https://www.iasj.net/iasj?func=article $\&$ ald $=43$ 376
Al-Fadhly, N.K.Z. (2009). Salting and drying of the Thelah fish (Scomberoides commersonianus) and studying its quality characteristics using sensory, chemical, physical and microbial indices. M. Sc. Thesis, Coll. Agric., Univ. Basrah. 195pp. (In Arabic).

Al-Hilphy, A.R.; Iskandar, M.Z. \& Abdul Hassan, K.H. (2011). A study of drying some vegetables and fruit by halogen oven. Kufa J. Agric. Sci., 3(2): 216-232. https://www.iasj.net/iasj?func=article \&aId $=12431$

Al-Hilphy, A.R.S. \& Al-Rikabi, A.K.J. (2013). Mathematical modelling experimental study on thin layer halogen dryer of strawberry and study it is effect on antioxidant activity. Am. J. Agri. Biol. Sci., $\quad$ 8(4): 268-281. https://doi.org/10.3844/aja bssp.2013

Ali, A.H.; Adday, T.K. \& Khamees, N.R. (2018). Catalogue of marine fishes of Iraq. Biol. Appl. Environ. Res., 2(2): 298-368. https://un.uobasrah.edu.iq/papers/10391.pd f

Al-Rubai'y, H.H.; Abdul Hassan, K.H. \& Eskandder, M.Z. (2020). Drying and salting fish using different methods and their effect on the sensory, chemical and microbial indices. Multidiscip. Rev., 3: 17. https://doi.org/10.29327/multi.2020003

Al-Shatty, S.M.H.; Al-Fadhly, N.K.Z. \& Salah, Y.A. (2013). Assessing the microbiological quality of salted and dried Thelah fish (Scomberoides commersonianus). Kufa J. Agric. Sci, $5(1)$ :

214-227. https://www.iasj.net/iasj?func=article \&aId $=65811$

Al-Shatty, S.M.H.; Al-Gwabrawy, A.A. \& Al-Hilphy, A.R.S. (2014). Study of 


\section{Al- Rubaiy et al. / Basrah J. Agric. Sci., 33(1): 231- 260, 2020}

chemical

and

microbiological

characteristics of dried Cyprians carpio by vacuum solar dryer (Locally manufactured) (Part 2). Thi-Qar Univ. J. Agric. Res., 3(1): 341-358. https://www.iasj.net/iasj?func=article \&aId $=94690$

Al-Temimi, A.; Aziz, S.N.; Al-Hilphy, A.R.; Lakhssassi, N.; Watson, D.G. \& Ibrahim, S.A. (2019). Critical review of radiofrequency (RF) heating applications in food processing. Food Qual. Saf., 3(2): 8191. https://doi.org/10.1093/fqsafe/fyz002

Al-Temimi, W.K.A. (2018). Studying of physical and chemical properties and microbial content for dried fish by microwave. Diyala J. Agric. Sci., 10(1): 12-28.

https://iasj. net/iasj?func=article \&ald=161966

Andrews, W. (1992). Manuals of Food Quality Control, 4. Microbiological analysis. FAO Food and Nutrition paper No.14/4 (Rev.1), Rome: 347pp. http://www.fao.org/3/T0610E/T0610E.pdf

Azam, K.; Basher, M.Z.; Ali, M.Y.; Asaduzzaman, M. \& Hossain, M.M. (2003). Comparative study of organoleptic, microbiological and biochemical qualities of four selected dried fish in summer and winter. Pak. J. Biol. Sci., 6(24): 20302033.

https://doi.org/10.3923/pjbs.2003.2030.203 3

Boeri, C.; Neto da Silva, F.; Ferreira, J.; Saraiva, J. \& Salvador, Â. (2011). Predicting the drying kinetics of salted codfish (Gadus morhua): Semi-empirical, diffusive and neural network models. Int. J. Food Sci. Technol., 46(3): 509-515. https://doi.org/10.1111/j.1365-

2621.2010.02513.x
Chen, X.; Fang, F. \& Wang, S. (2020). Physicochemical properties and hepatoprotective effects of glycated Snapper fish scale peptides conjugated with xylose via maillard reaction. Food Chem. Toxicol., 137: 111115. https://doi.org/10.1016/j.fct.2020.111115

Darvishi, H.; Azadbakht , M.; Rezaeiasl, A. \& Farhang, A. (2013). Drying characteristics of sardine fish dried with microwave heating. J. Saudi Soc. Agric. Sci., 12(2): 121-127. https://doi.org/10.1016/j.jssas.2012.09.002

Deng, Y.; Wang, R.; Wang, Y.; Sun, L.; Tao, S.; Li, X. \& Zhao, J. (2020). Diversity and succession of microbial communities and chemical analysis in dried Lutianus erythropterus during storage. Int. J. Food Microbiol., $\quad 314$ : 108416. https://doi.org/10.1016/j.ijfoodmicro.2019. 108416

Dubey, A.; Sagar, A.; Malkani, P.; Choudhary, M.K. \& Ramnath, S.S. (2020). A comprehensive review on greenhouse drying technology. J. Agric. Ecol. Res. Int., 10-20. https://doi.org/10.9734/JAERI/2020/v21i1 30123

Egan, H.; Kirk, R.S. \& Sawyer, R. (1988). Pearson's Chemical Analysis of Foods. $8^{\text {th }}$ ed. Longman Scientific and Technical, The Bath Press, 591pp.

El-Sebaiy, L.A. \& Metwalli, S.M. (1989). Changes in some chemical characteristics and lipid composition of salted bouri fish muscle (Mugil cephalus). Food Chem., 31(1): 41-50. https://dx.doi.org//0.1016/0308-8146

Fath El-Bab, G.F.A. (2005). Health hazard associated with salted fish in Egyptian market. Egyp. J. Agric. Res., 83(1): 405- 
410.

https://doi.org/10.1016/j.jssas.2012.09.002

Fricke, R., Eschmeyer, W.N. \& Fong, J.D. (2020). Species by family/subfamily. California: Institute for Biodiversity Science and Sustainability, California Academy of Science. Electronic version $\begin{array}{llll}\text { accessed } & 6 & \text { April } & 2020 .\end{array}$ http://researcharchive.calacademy.org/rese arch/ichthyology/catalog/SpeciesByFamily .asp

Froese, R. \& Pauly, D. (eds.) (2019). Fish Base. World Wide Web electronic publication. (Version 12/ 2019). http://www.fishbase.org./

Gates, K.W. (2015). Seafood processing: technology, quality and safety. J. Aquat. Food Product Technol., 24(1): 91-97. https://doi.org/10.1080/10498850.2014.95 4475

Guiné, R. (2018). The drying of foods and its effect on the physical-chemical, sensorial and nutritional properties. Int. J. Food Eng., $\quad 2(4)$ : 93-100. https://doi.org/10.18178/ijfe.4.2.93-100

Hardoko, H. \& Utami, S. (2020). Chemicalphysical properties characterization of white snapper fish skin rambak crackers based on boiling and drying duration. J. Ilmiah Perikanan dan Kelautan, 12(1): 122-130.

http://doi.org/10.20473/jipk.v12i1.14842

Hernandez-Perez, J.A.; Garcia-Alvarado, M.A.; Trystram, G. \& Heyd, B. (2004). Neural networks for the heat and mass transfer prediction during drying of cassava and mango. Innov. Food Sci. Emerg. Technol., 5: 57-64. https://doi.org/10.1016/j.ifset.2003.10.004
Huss, H.H. (1995). Quality and Quality Changes in Fresh Fish. FAO Fisheries Technical Paper, No. 348. Rome, FAO: 195pp.

Kiin-Kabari, D.B. \& Obasi, N. (2020). Effect of drying on the rehydration properties of some selected shellfish. Asian Food Sci. J., 14(1):

42-48. https://doi.org/10.9734/AFSJ/2020/v14i13 0122 .

Krokida, M.K. \& Morinos-Kouris, D. (2003). Rehydration kinetics of dehydrated products. J. Food Eng., 57: 1-7. https://doi.org/10.1016/S02608774(02)002 14-5

Kubra, K., Hoque, M. S., Hossen, S., Husna, A.U., Azam, M., Sharker, M.R. \& Ali, M. M. (2020). Fish drying and socioeconomic condition of dried fish producers in the coastal region of Bangladesh. Middle-East J. Sci. Res., 28(3): 182-192. https://doi.org/10.5829/idosi.mejsr.2020.18 2.192

Kumar, Y. (2015). Application of microwave in food drying. Int. J. Eng. Stu. Tech. Apr., 1(6): 9-24. http://ijesta.com/upcomingissue/02.06.201 5.pdf

Lasisi, O.I.; Fapetu, O.P. \& Akinola, A.O. (2020). Development of a solar dryer incorporated with a thermal storage mechanism. Dev. Int. J. Adv. Sci. Res. Eng., $\quad 6(1)$ : $134-146$. http://doi.org/10.31695/IJASRE.2020.3369 4

Lim, G.W.; Jafarzadeh, S. \& Norazatul Hanim, M.R. (2020). Kinetic study, optimization and comparison of sun drying and superheated steam drying of asam gelugor (Garcinia cambogia). Food Res., 
Al- Rubaiy et al. / Basrah J. Agric. Sci., 33(1): 231- 260, 2020

4(2):

396-406.

https://doi.org/10.26656/fr.2017.4(2).288

Lithi, U.J.; Surovi, S.; Faridullah, M. \& Roy, K.C. (2020). Effects of drying technique on the quality of Mola (Amblypharyngodon mola) dried by solar tent dryer and open sun rack dryer. Res. Agric. Livest. Fish., 7(1): 121-128. https://doi.org/10.3329/ralf.v7i1.46840

Majeed, G.H. \& Al-Hilphy, A.R.S. (2007). Design of a solar dryer provided with back and heating systems and its testing in the drying of fishes and meats. J. Basrah Res., 33(3): 20-30. https://www.iasj.net/iasj?func=article \&aId $=57643$

Mohamed, A.R.M.; Abood, A.N. \& Hussein, S.A. (2016). Comparative taxonomical study of four mullet species (Mugiliformes: Mugilidae) from Iraqi marine waters, Arabian Gulf. Basrah J. Agric. Sci., 23(2): 11-23. (In Arabic). https://iasj.net/iasjAdmin?func=fulltext $\&$ aI $\mathrm{d}=120189$

Nur, I.T.; Ghosh, B.K. \& Acharjee, M. (2020). Comparative microbiological analysis of raw fishes and sun-dried fishes collected from the Kawran bazaar in Dhaka city, Bangladesh. Food Res., 4(3), 846-851.

https://doi.org/10.26656/fr.2017.4(3).368

Özilgen, M. (1998). Food Process Modeling and Control: Chemical Engineering Applications. $\quad$ CRC.: 518pp. https://www.routledge.com/Handbook-ofFood-Process-Modeling-and-StatisticalQualityControl/Ozilgen/p/book/978143981 4864

Pan, Z. \& Atungulu G.G. (2011). Infrared Heating for Food and Agricultural Processing. CRC Press: 300pp.
https://www.routledge.com/Infrared-Heatingfor-Food-and-Agricultural-Processing/PanAtungulu/p/book/9780367383787

Patir, B.; Gurelinanli, A.; Oksuztepe, G. \& Irfan Ilhak, O. (2006). Microbiological and chemical qualities of salted grey mullet (Chalcalburnus tarichii Pallas, 1811). Int. J. Food Sci. Technol, 1(2): 91-98. https://doi.org/10.1016/j.sjbs.2017.04.003

Pochont, N.R.; Mohammad, M.N.; Pradeep, B.T. \& Kumar, P.V. (2020). A comparative study of drying kinetics and quality of Indian red chilli in solar hybrid greenhouse drying and open sun drying. Mater. Today Proc., 21: 286-290. https://doi.org/10.1016/j.matpr.2019.05.43 3

Rangana, S. (1976). Manual of Analysis of Fruit and Vegetable Products. 1st Edn., Tata MaGraw-Hill, New Delhi: 634pp.

Rasul, M.; Majumdar, .C.; Afrin, F.; Bapary, M.A. \& Shah, A.K. (2018). Biochemical, microbiological and sensory properties of dried silver carp (Hypophthalmichtys molitrix) influenced by various drying methods. $\quad$ Fishes, 3(3): 25. https://doi.org/10.3390/fishes 3030025 .

Rossini, K.; Norena, C.P.; Cladera-Olivera, F. \& Brandelli, A. (2009). Casein peptides with inhibitory activity on lipid oxidation in beef homogenates and mechanically deboned poultry meat. LWT-Food Sci. Technol., $\quad$ 42(4): $\quad$ 862-867. https://doi.org/10.1016/j. lwt.2019.108633

Scanlin, D. (1997). The design, construction, and use of an indirect, through-pass, solar food dryer. Home Power \#57: 62-72. https://www.rivendellvillage.org/Solar_Fo od_Dryer.pdf

Nath, S.; Ranjan, A.; Mohanty, B.P.; Saklani, P.; Dora, K.C. \& Chowdhury, S. (2020). 
Al- Rubaiy et al. / Basrah J. Agric. Sci., 33(1): 231- 260, 2020

Dry fish and its contribution towards food and nutritional security. Food Rev. Int., 2020:

$29 \mathrm{pp}$.

https://doi.org/10.1080/87559129.2020.17

37708

Solanki, J.B. (2020). Different types of fish drying methods in Gujarat. Int. J. Fish. Aquat. $\quad$ Stud., $8(1)$ : 129-131. http://www.fisheriesjournal.com/archives/? year $=2020 \&$ vol $=8 \&$ issue $=1 \&$ part $=$ B $\&$ Arti cleId $=2102$

Stannard, C. (1997). Development and use of microbiological criteria for foods. J. Food Sci. Tech., 11(3): 137-177. https://doi.org/10.1.1.474.2198\&rep
Tanuja, S.; Mhatre, C.S.; Mohanty, G.; Rout, E.; Rout, P. \& Srivastava, S.K. (2020). Development of low cost solar rack dryer and comparative biochemical quality evaluation of anchovies (Stolephorus commersonii) dried in sun and solar rack dryer. Int. J. Curr. Microbiol. App. Sci., 9(3): 579-586. https://doi.org/10.20546/ijcmas.2020.903.0 68

Toledo, R.T. (2007). Fundamentals of Food Process Engineering. 1st edn., Springer, New $\quad$ York: 600pp. https://www.springer.com/gp/book/978146 1570523

\title{
تجفيف اسماك بياح كلوزنجر Planiliza klunzingeri باستخدام مجفف الهالوجين ونمذجة محتوى الرطوية باستخدام الشبكة العصبية الاصطناعية
}

\author{
حسن هادي الربيعي وصباح مالك الشطي واسعد رحمان الحلفي \\ قسم علوم الاغذية، كلية الزراعة، جامعة البصرة، العراق
}

المستخلص: تم تجفيف اسماك بياح كلوزنجر Planiliza klunzingeri المملحة و غبر المملحة باستخدام مجفف هالوجين الذي يعمل بالأشعة تحت الحمر اء بدرجات حرارة مختلفة (60 ، 65 ، 70 ، 75 و 80 مئوي) وفترات تخزين مختلفة (0 ، 7 ، 14 ،

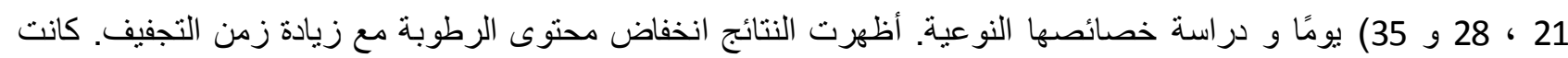
كفاءة التجفيف لمجفف الهالوجين 70.36٪ عند 60 درجة مئوية وانخفضت مع زيادة درجة حرارة التجفيف. أظهر التركيب الكيميائي للأسماك المجفة (المملحة وغير المملحة) انخفاض نسبة الرطوبة، ولكن نسبة البروتين والدهون و الرماد زادت بعد عملية التجفيف. زادت نسبة الرطوبة خلال فترات التخزين (0، 7، 14، 21، 28 و35) يومًا، على عكس نسب التبه التركيب الكيميائي الأخرى انخفضت مع زيادة فترات التخزين. أوضحت النتائج انخفاض الاسترجاع مع زيادة درجات حرارة التجفيف للأسماك المجفة المملحة وغير المملة. علاوة على ذلك، أظهرت النتائج أن هناك زيادة في TBA بعد عملية التجفيف وأثناء فترات التخزين. بالإضافة إلى ذلك، أظهرت النتائج انخفاض المحتوى الميكروبي للأسماك المملحة وغير المملحة. أوضحت النتائج أنه بمكن استخدام موديل الرتبة الأولى للتنبؤ بقيمة الرقم الهيدروجيني خلال فترات التخزين. اعطى موديل الثبكة العصبية الاصطناعية (ANN) نتيجة جيدة لمحتوى الرطوبة المتنبأ به.

الكلمات الدفتاحية: الأسماك، الشبكة العبية الاصطناعية، Planiliza klunzingeri، مجف الهالوجين، الخصائص النوعبة، المحتوى الميكروبيولوجي. 